Article

\title{
A Systematic Review: Is Aedes albopictus an Efficient Bridge Vector for Zoonotic Arboviruses?
}

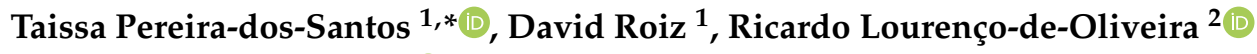 \\ and Christophe Paupy $1, *$ (D) \\ 1 MIVEGEC, Univ. Montpellier, IRD, CNRS, 34090 Montpellier, France; david.roiz@ird.fr \\ 2 LATHEMA, Instituto Oswaldo Cruz, FIOCRUZ, Rio de Janeiro-RJ 4364, Brazil; lourenco@ioc.fiocruz.br \\ * Correspondence: tayssadnz@gmail.com (T.P.-d.-S.); christophe.paupy@ird.fr (C.P.)
}

Received: 15 March 2020; Accepted: 4 April 2020; Published: 7 April 2020

\begin{abstract}
Mosquito-borne arboviruses are increasing due to human disturbances of natural ecosystems and globalization of trade and travel. These anthropic changes may affect mosquito communities by modulating ecological traits that influence the "spill-over" dynamics of zoonotic pathogens, especially at the interface between natural and human environments. Particularly, the global invasion of Aedes albopictus is observed not only across urban and peri-urban settings, but also in newly invaded areas in natural settings. This could foster the interaction of Ae. albopictus with wildlife, including local reservoirs of enzootic arboviruses, with implications for the potential zoonotic transfer of pathogens. To evaluate the potential of Ae. albopictus as a bridge vector of arboviruses between wildlife and humans, we performed a bibliographic search and analysis focusing on three components: (1) The capacity of Ae. albopictus to exploit natural larval breeding sites, (2) the blood-feeding behaviour of Ae. albopictus, and (3) Ae. albopictus' vector competence for arboviruses. Our analysis confirms the potential of Ae. albopictus as a bridge vector based on its colonization of natural breeding sites in newly invaded areas, its opportunistic feeding behaviour together with the preference for human blood, and the competence to transmit 14 arboviruses.
\end{abstract}

Keywords: Aedes albopictus; emerging diseases; vector competence; spill-over; blood-feeding; bridge vector; arboviruses; mosquito

\section{Introduction}

The human alteration of Earth's natural systems has become a great concern and a threat to human health. Indeed, these changes are likely to drive most of the global disease burden over the coming century [1]. During the last decades, the burden of emerging infectious diseases has increased to represent a substantial threat to global health, security, and economy growth. About $75 \%$ of emerging infectious diseases are zoonotic diseases, mostly of wildlife origin [2,3]. The risk of zoonotic emergences is considered high in tropical forest regions associated with a range of facilitating factors, particularly high vertebrate species diversity and agricultural land use changes [4]. Understanding the mechanisms of disease emergence allows the development of early detection and control programs for reducing disease incidence and economic burden [5].

Zoonotic pathogens can be transmitted from animals to humans directly, or indirectly when arthropod vectors are needed to accomplish their life cycle. Zoonotic vector-borne diseases are maintained in enzootic cycles, but can be transmitted from animal reservoir populations to sympatric human populations or to domestic animals during "spill-over events", and also from humans to animals during "spill-back events" [2,6]. The global emergence of vector-borne diseases is helped by international travel and trade, after their local emergence has been driven by a combination of environmental changes that are not yet completely understood [7]. Therefore, research is needed to 
determine the potential of these pathogens to emerge in the future, and to identify critical geographic areas where early warning systems must be put in place to mitigate the pathogen's impact on human health [8].

Here, we focused on zoonotic arboviruses (arthropod-borne viruses) transmitted by mosquitoes that are part of enzootic cycles evolving in wildlife or domestic animals, independently of mankind. Animals might act as amplification hosts for spill-over events to humans [9], mainly in tropical forest environments [10]. Some arboviruses, such as those causing epidemic Aedes-borne viral diseases (dengue, chikungunya, and zika), have adapted to epidemic cycles in which viremic humans became the source of infection in urban areas where Aedes aegypti, and to a lesser extent, Aedes albopictus [11,12] ensure person-to-person transmission [13]. The burden of Aedes-borne diseases is dramatic. For instance, dengue incidence has increased by 30 times over the last 50 years, with about 390 million infections reported annually worldwide $[14,15]$. Dengue and chikungunya outbreak waves have resulted in several million cases in the Southwest Indian Ocean region, India, and the Americas [16]. Zika virus (ZIKAV) disease emerged in 87 countries (or territories) [17]. ZIKAV infection during pregnancy can cause microcephaly in newborns and is becoming a major threat due to its long-term sanitary and economic impacts, especially in Latin America [18]. Although these infection outbreaks are caused by independent urban cycles, enzootic cycles still remain essential sources of pathogens and/or vectors that can be introduced, adapt, and disperse, causing new severe threats [2], as exemplified by the recent re-emergence of Yellow Fever Virus (YFV) in Brazil, Angola, and the Democratic Republic of Congo $[19,20]$. For YFV, spill-over events from non-human primates that involve mosquito bridge vectors have been described in tropical Africa (e.g., involving Aedes africanus or Aedes furcifer) [21] and in America (involving mosquito species from the Haemagogus and Sabethes genera) [20]. After its introduction in the Americas, YFV has efficiently spilled back into sylvatic cycles via bridge vectors. In African villages or cities, YFV transmission is supported by epidemic vectors, such as Ae. aegypti [21,22]. These data indicate that mosquito bridge vectors play key roles in the early processes leading to the emergence of enzootic viruses, before the urban transmission cycles [6,8].

We define a bridge vector as an "appropriate hematophagous arthropod" that ensures the biological transmission of a pathogen across different landscapes and its circulation between enzootic, domestic animal, and human hosts. In the absence of a bridge vector, pathogen transmission generally remains restricted to a specific area within the enzootic or epidemic cycle and among hosts/reservoirs. Bridge vectors are the key that interconnects animal reservoirs to new vertebrate hosts, including humans, and that allows both spill-over and spill-back events. For this study, we considered that bridge vectors show several bio-ecological traits that influence the shifting risks of pathogen transfer and that are mainly related to their ecological distribution, blood feeding behaviour, and vector competence. Regarding ecological habitats, high ecological and physiological plasticity favours the vector dispersal and its establishment (breeding in specific microhabitats) across different ecosystems, landscapes, or habitats (e.g., forest/rural/urban, forest/savannah, ground/canopy, natural/anthropic larval breeding and adult resting sites). Regarding blood feeding behaviour, low specificity in blood-meal sources and opportunistic feeding behaviour involving multiple hosts increases the probability of contact between the vector and different animal reservoirs, and thus interspecies pathogen transfer. This probability also depends on the vector and host density and on the host's defensive behaviour. Regarding vector competence, for the biological transmission of a pathogen after its acquisition on an infected vertebrate, a bridge vector must be able to ensure its replication/multiplication, dissemination, and transmission to subsequently bitten vertebrates. Arthropod species competent for a large panel of pathogens or with high vector competence for one pathogen represent particularly suitable candidates to act as (bridge) vectors.

Here, we evaluated the potential role of the Asian tiger mosquito Ae. albopictus as a bridge vector. This invasive vector species originates from Asian tropical forests, but nowadays is present in all continents [23], and has become a major public health issue. In its native area, sylvatic Ae. albopictus populations complete their biological cycle by exploiting wild animals as blood sources, and natural 
water collection points (e.g., tree holes, bamboo stumps, or rock holes) as oviposition sites in the woods [24], particularly at the forest edge [24]. The capacity to colonize artificial man-made containers (together with desiccation-resistant and diapausing eggs) led to its "domestication". Its ecological plasticity to several habitats, its passive dispersion through the global transport of tires and inside cars [25], and the inefficiency of control programmes have allowed Ae. albopictus to become one of most invasive species worldwide [23,24]. In native and newly colonized areas, it has been found in urban, rural, and forest habitats; however, unclear information is available on its natural breeding sites and its presence in forested environments. Moreover, its presence in natural breeding sites in the invaded territories has not been analysed. In general, Ae. albopictus is considered an opportunistic feeder that is attracted to mammals, particularly humans, rather than other hosts [26,27]. However, to our knowledge, a detailed and quantified analysis of its host preferences has never been done.

In relation to epidemic virus transmission, Ae. albopictus has been considered the vector for the chikungunya virus (CHIKV), dengue virus (DENV), and ZIKAV in Gabon and Central Africa [28,29], for DENV and CHIKV in la Réunion island [30], and for CHIKV in Madagascar and Mayotte [30,31]. In Europe, it has been incriminated in Italy and France during CHIKV and DENV outbreaks [32,33] and in Japan in DENV transmission [34]. Moreover, this mosquito represents a potential risk of outbreaks in many other areas, for example, in Brazil and USA where Ae. albopictus is widespread [35-38]. Different studies have shown that Ae. albopictus can develop infection from up to 32 arboviruses [16,23,36]; however, to our knowledge, its ability to transmit any of them has not been clearly demonstrated yet.

In this work, we hypothesized that Ae. albopictus may have an active role as a bridge vector for the transfer from vertebrate hosts to humans (spill-over events) and therefore, in the emergence of enzootic arboviruses. To test this hypothesis, we reviewed and quantified: (1) Ae. albopictus' capacity to exploit natural water collections as larval breeding sites (as a proxy for its establishment in rural/sylvatic/forested areas) in native or invaded regions; (2) its feeding behaviour with regard to humans, domestic, or wild animals (as a proxy for the contact between vertebrate hosts and humans); and (3) its vector competence, tested experimentally for different arboviruses and natural infections reported from the field in mosquitoes (as a proxy for its potential for virus transmission in the field). Finally, we discuss the potential spill-over transmission risk from vertebrate hosts to humans and the methodological issues and knowledge gaps that need to be tackled.

\section{Results}

\subsection{Natural Breeding Sites}

Based on the literature (see Methods and Supplementary Tables S1 and S2), we found 27 articles that quantified the number and type of natural breeding sites exploited by Ae. albopictus in areas where the species is considered native ( $\mathrm{n}=10$ articles) or invasive (i.e., colonized areas) ( $\mathrm{n}=17$ articles). Preimaginal stages of Ae. albopictus were mainly detected in coconut shells (54.7\%) [37-45], bromeliads (19\%) [46-50], bamboo stumps (8.3\%) [39,40,51-54], tree holes (8.2\%) [37,42,43,51,53-59], palm leaves (3.6\%) [51], rock holes $(3.2 \%)[37,42,43,51,53,57,60]$, leaf axils $(1 \%)[39,40,42,61]$, and sporadically $(<1 \%)$ in other natural breeding sites, such as snail shells [43,53], palm bracts [53], dead leaves [37,43], cacao pods on the ground [43], dead cow horns [43], puddles [62], ground cavities [46], and hollow logs [53] (Figure 1). 


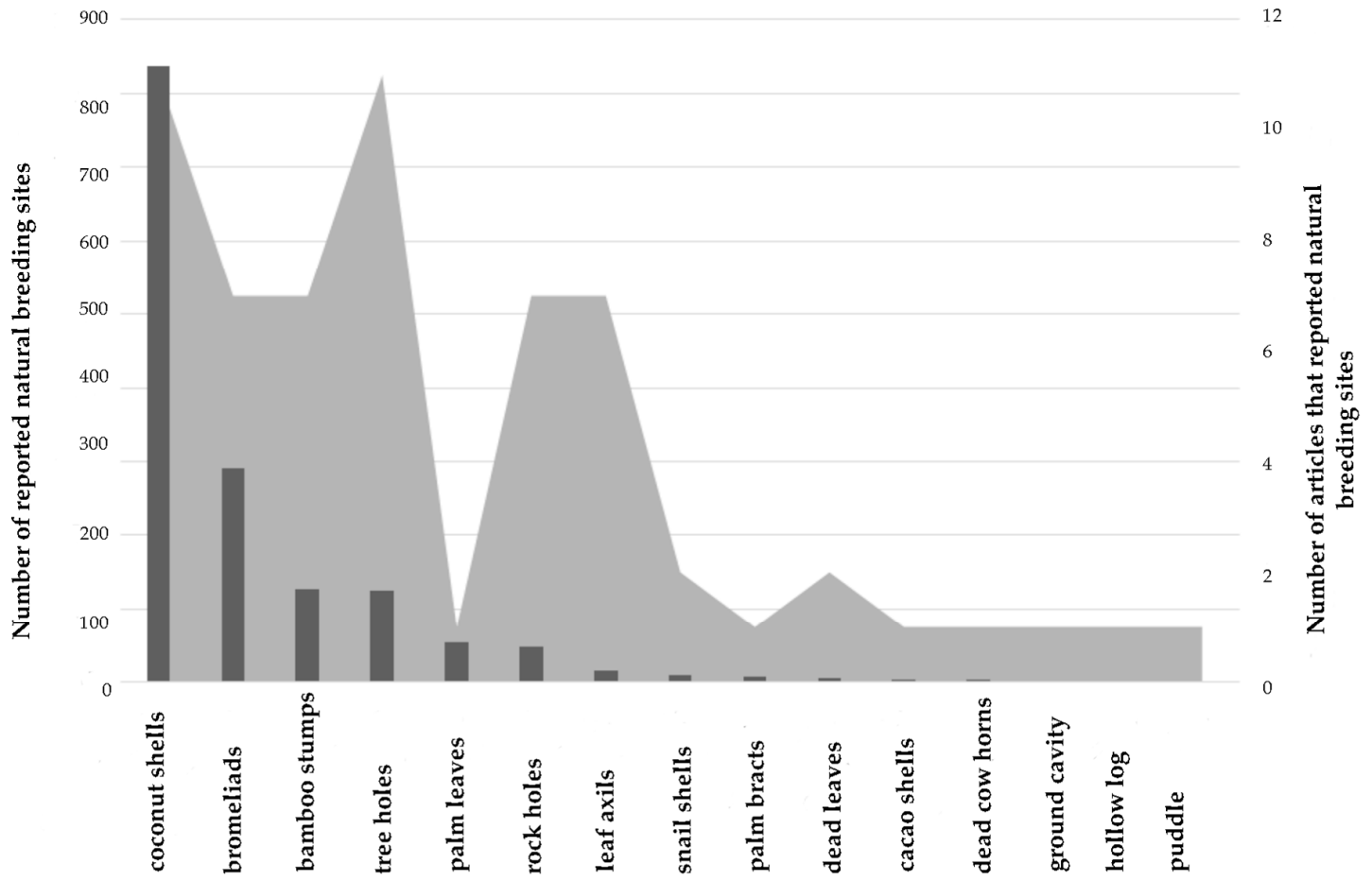

Figure 1. Natural larval breeding sites exploited by Ae. albopictus. Number of reported natural breeding sites (black bars) and number of articles that reported natural breeding sites (grey areas).

Coconut shells and tree holes were more often reported (11 articles each), followed by bamboo stumps, bromeliads, rock holes, and leaf axils ( 7 articles each), and finally, the other natural breeding sites (1-2 articles each). In native areas, most of the reported natural breeding sites were coconut shells $(83 \%)$, followed by bamboo stumps $(11 \%)$, tree holes $(5 \%)$, leaf axils $(1 \%)$, and rock holes $(1 \%)$. In colonized areas, a great diversity of breeding sites was reported: bromeliads (50.8\%), tree holes $(13 \%)$, palm leaves $(9.6 \%)$, rock holes $(8.4 \%)$, coconut shells $(8 \%)$, bamboo stumps $(3.8 \%)$, leaf axils $(1 \%)$, palm bracts $(1.2 \%)$, snail shell $(1.7 \%)$, and others $(<1 \%$ each).

\subsection{Feeding Behaviour}

Our quantification of the feeding behaviour indicates that Ae. albopictus has been mainly reported as a species that prefers mammals (including humans) as blood sources (mean and standard deviation: $92.0 \% \pm 8)$, compared with birds $(8 \% \pm 8)$ and other animals $(3.7 \% \pm 1.7)[26,27,63-82]$ (Figure $2 \mathrm{~A})$. Among mammals, blood meals were mainly from humans (60\%) than non-human species (30\%). From an "interspecies risk of transfer" perspective, it is relevant to note that Ae. albopictus seems to be biting domestic animals (25\%) more frequently than wildlife animals (10\%) (Figure 2B). Importantly, there is huge variability in the percentage of human blood meals in the different studies. 
A)
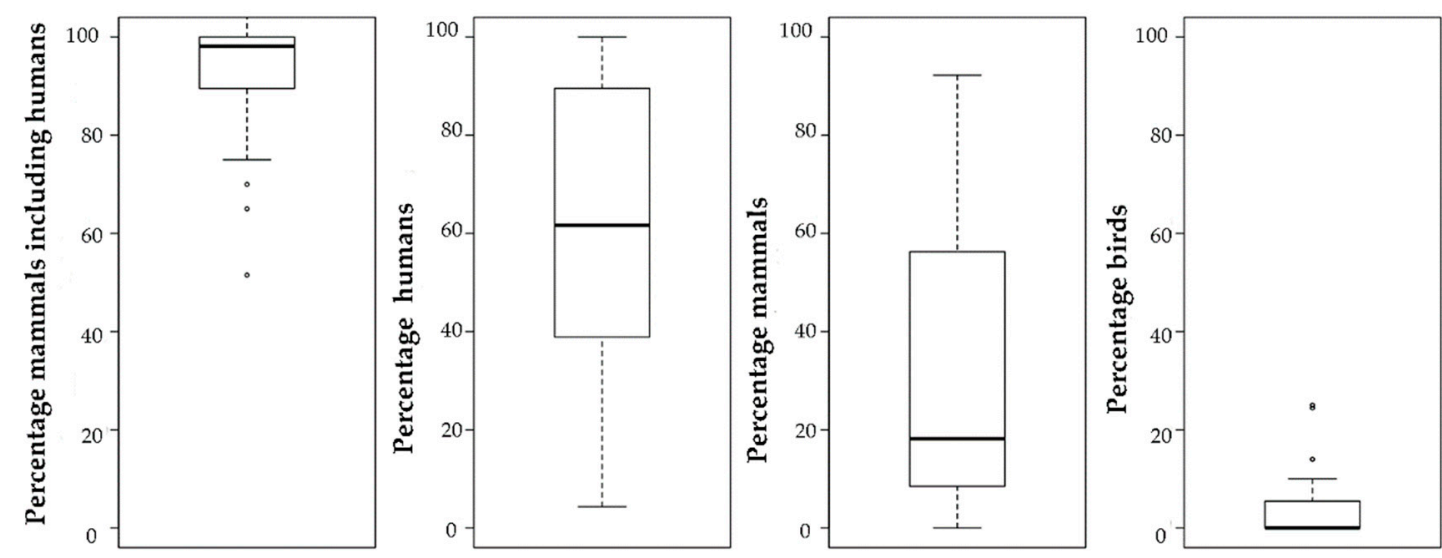

B)
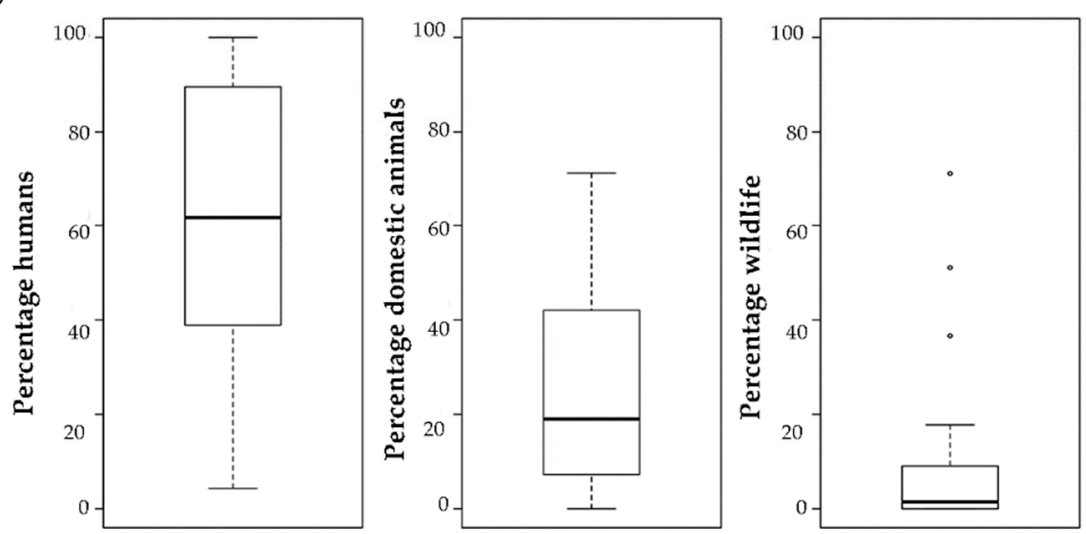

Figure 2. Boxplots showing the host feeding preferences (i.e., percentage of bites) of Ae. albopictus without taking into account host availability. (A) Mammals, humans, non-human mammals, and birds; (B) Humans, domestic animals, and wildlife. Black line: median.

Among domestic and peri-domestic animals, dogs, rodents, and rabbits were reported as the main blood sources for Ae. albopictus, followed by cats, bovines, chickens, horses, and pigs (Supplementary Figure S1). When classified according to the biological family of blood sources, Ae. albopictus can feed on 28 different host biological families, and preferentially on animals belonging to Hominidae (60\%), Muridae (15\%), Canidae (12\%), and Phasianidae (10\%) (see Table 1 for detailed information and Supplementary Table S3 for bibliographical information). 
Table 1. Mean biting frequency by Aedes albopictus in animals classified according to biological class and family.

\begin{tabular}{|c|c|c|}
\hline Biological Class & Biological Family & Mean Frequency (\%) \\
\hline \multirow{9}{*}{ Aves } & Phasianidae & 10.08 \\
\hline & Passeridae & 7.78 \\
\hline & Anatidae & 7.5 \\
\hline & Columbidae & 5.83 \\
\hline & Sulidae & 2.33 \\
\hline & Thamnophilidae & 1.49 \\
\hline & Pycnonotidae & 1.39 \\
\hline & Corvidae & 1.11 \\
\hline & Ciconiidae & 1.0 \\
\hline \multirow{17}{*}{ Mammalia } & Hominidae (Humans) & 59.83 \\
\hline & Muridae & 15.34 \\
\hline & Canidae & 11.6 \\
\hline & Herpestidae & 9.53 \\
\hline & Bovidae & 8.9 \\
\hline & Felidae & 8.49 \\
\hline & Leporidae & 8.27 \\
\hline & Sciuridae & 5.07 \\
\hline & Suidae & 4.99 \\
\hline & Didelphidae & 4.6 \\
\hline & Equidae & 4.39 \\
\hline & Cervidae & 4.15 \\
\hline & Muridae/Soricidae & 3.43 \\
\hline & Phyllostomidae & 2.99 \\
\hline & Procyonidae & 2.71 \\
\hline & Furipteridae & 1.49 \\
\hline & Cricetidae & 0.61 \\
\hline Actinopterygii & Cobitidae & 1.11 \\
\hline Amphibia & Salamandridae & 2.22 \\
\hline
\end{tabular}

The mean frequencies were calculated using the data found in articles that described different $A$ e albopictus populations biting different animals in different locations. As these articles do not describe the same biological families, the total mean bite frequency does not correspond to $100 \%$.

\subsection{Arbovirus Transmission}

In the literature search, in addition to the epidemic DENV (serotypes 1, 2, 3, and 4), CHIKV and ZIKV, we found reports on experimental infections of Ae. albopictus with the following 36 arboviruses: Arumowot (AMTV) [83], Bujaru (BUJV) [83], Bussuquara (BSQV) [84], Cache Valley (CVV) [85], Chandipura (CHPV) [86], Chilibre (CHIV) [83], Eastern Equine Encephalomyelitis (EEEV) [87-90], Getah (GETV) [91], Icoaraci (ICOV) [83], Ilheus (ILHV) [92], Itaporanga (ITPV) [83], Jamestown Canyon (JCV) [93], Japanese Encephalitis (JEV) [92,94-96], Karimabad (KARV) [83], Keystone (KEYV) [92,93], Kokobera (KOKV) [92], Kunjin (KUNV) [92], La Crosse (LACV) [92,93,97-99], Mayaro (MAYV) [100], Oropuche (OROV) [100], Orungo (ORUV) [101], Pacui (PACV) [83], Potosi (POTV) [102-104], Rift Valley fever (RVFV) [105,106], Ross River (RRV) [107,108], Salehabad (SALV) [83], San Angelo (SA) [84,92,109], St. Louis encephalitis (SLEV) [110], Tensaw (TENV) [111], Trivittatus (TVTV) [93], Uganda S. (UGSV) [92], Urucuri (URUV) [83], Usutu virus (USUV) [112], Venezuelan equine encephalitis (VEEV) [113-115], West Nile virus (WNV) [116-125], and YFV [108,126-130] (see Supplementary Table S4 for bibliographical information). However, besides the addition to the epidemic DENV (serotypes 1, 2, 3 and 4) [131], CHIKV, and ZIKV [28], natural infections of Ae. albopictus were only reported for eight viruses: CCV [85,132], EEEV [133], KEYV [133], LACV [99,132,134,135], POTV [102,132,136], TENV [133], USUV [112], and WNV [118-120] (see Supplementary Table S5 for bibliographical information). These infections were detected by virus isolation on cell lines, immunological or 
molecular methods (Vero cells, direct or indirect immunofluorescence, polymerase chain reaction). These infections provide evidence of contact between Ae. albopictus and the hosts of these viruses, but do not necessarily indicate their biological transmission by this mosquito. On the other hand, for the BSQV, ILHV, KOKV, KUNV, and UGSV arboviruses, only intrathoracic injection experiments were carried out to investigate transovarian transmission between different generations. Supplementary Table S6 gives information on the taxonomic classification of these viruses, their geographic distribution, their natural host family (i.e., vertebrate host family in which the virus was isolated or in which serological evidence was found), the mosquito species from which the virus was isolated, and the detection method in Ae. albopictus.

Among studies on Ae. albopictus vector competence, we found important variations concerning the methodology used to perform the infection (intra-thoracic inoculation of viruses, oral challenge using infected blood meals or infected animals), the mosquito strains, the viral strains and the virus loads used, the conditions of mosquito incubation (e.g., time, temperature), and the methods used to determine mosquito infection and transmission efficiency. Concerning the virus inoculation methodology, intra-thoracic injection was used for 11 viruses to assess vector infection, and oral infection was performed using infected hosts ( $\mathrm{n}=11$ arboviruses), or membrane feeding methods ( $\mathrm{n}=11$ arboviruses).

The mean infection values in Ae. albopictus after infection by intrathoracic injection greatly varied in function of the tested virus, and ranged from $100 \% \pm 0$ (AMTV, BUJV, and PACV) to $37.5 \% \pm 17.67$ (ORUV). Among these viruses, the transmission rate after intrathoracic injection was estimated only for ORUV (37.5\% \pm 17.67$)$ and RVFV (15.9\% \pm 7.3$)$. The mean infection rate (IR) in Ae. albopictus that fed directly on infected vertebrate hosts or on an infectious artificial blood-meal through a membrane also hugely varied, from $100 \% \pm 0$ for GETV to $6.6 \% \pm 5.2$ for OROV. The mean Dissemination Efficiency (DE) in Ae. albopictus varied from $89.85 \% \pm 5.9$ for POTV to $4.06 \% \pm 1.32$ for MAYV. The mean Transmissions Rates (TR) in Ae. albopictus varied from $82.7 \% \pm 11.5(\mathrm{WNV})$ to $7.7 \% \pm 0(\mathrm{JCV})$. Finally, the mean Transmission Efficiency (TE) by Ae. albopictus varied from $68.6 \% \pm 18.6$ (WNV) to $3.5 \% \pm 0.69$ (MAYV).

Whatever the methodology used for the experimental infection, transmission was confirmed for 14 viruses. Six displayed a mean TE higher than 30\% (WNV, EEEV, RRV, JEV, VEEV, and ORUV), and five had a mean TE between 10\% and 30\% (LACV, CVV, POTV, CHPV, and RVFV). The mean TE for YFV, JCV, and MAYV was below 10\%. All TE rates in Ae. albopictus (using both experimental infections with infectious animals and infectious artificial blood meals) are summarized in Figure 3 , without taking into account the different mosquito populations used, the viral loads, or genotypes. For more details on the infection parameters (IR, DE, TR, and TE) obtained using the different inoculation methods, see Table 2. 

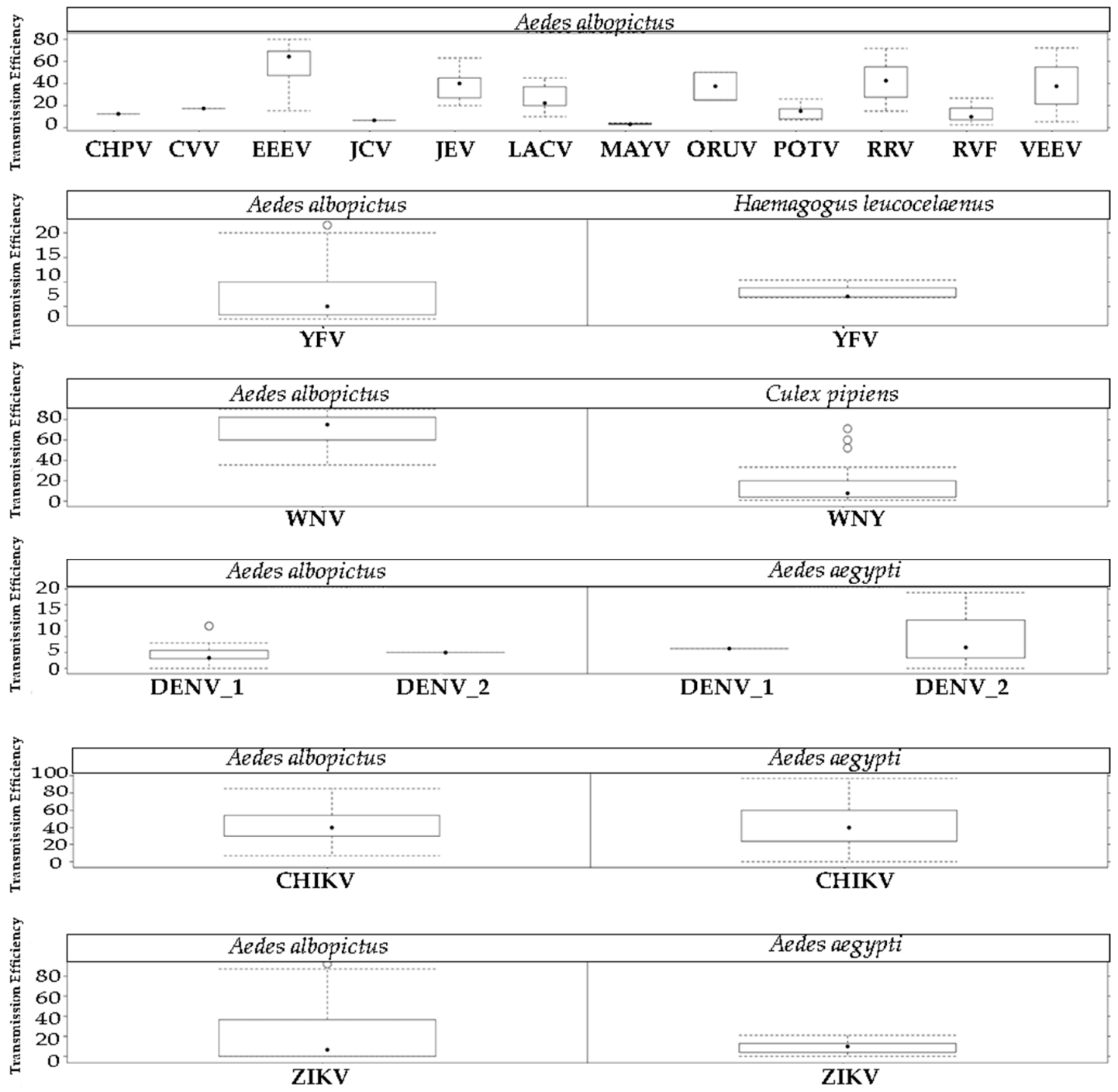

Figure 3. Transmission efficiency across studies that evaluated Ae. albopictus vector competence for different arboviruses. Bridge Vector*Virus and Epidemic Vector*Virus pairs were added to compare the transmission efficiency. 
Table 2. Infection rate, dissemination rate, dissemination efficiency, transmission rate, and transmission efficiency (mean and standard deviation) of Aedes albopictus for the indicated arboviruses, according to the inoculation method.

\begin{tabular}{|c|c|c|c|c|c|c|c|c|c|c|c|}
\hline \multirow[t]{2}{*}{$\begin{array}{l}\text { Infection } \\
\text { Method }\end{array}$} & \multirow[t]{2}{*}{ Virus } & \multicolumn{2}{|c|}{$\begin{array}{c}\text { Infection or } \\
\text { Infection Rate }\end{array}$} & \multicolumn{2}{|c|}{$\begin{array}{c}\text { Dissemination } \\
\text { Rate }\end{array}$} & \multicolumn{2}{|c|}{$\begin{array}{l}\text { Dissemination } \\
\text { Efficiency }\end{array}$} & \multicolumn{2}{|c|}{$\begin{array}{c}\text { Transmission } \\
\text { Rate }\end{array}$} & \multicolumn{2}{|c|}{$\begin{array}{c}\text { Transmission } \\
\text { Efficiency }\end{array}$} \\
\hline & & Mean & SD & Mean & SD & Mean & SD & Mean & SD & Mean & SD \\
\hline \multirow{11}{*}{ Host feeding } & $\mathrm{CHPV}$ & 25.00 & 0.00 & ND & ND & ND & ND & ND & ND & 12.50 & 0.00 \\
\hline & EEEV & 75.36 & 35.35 & 85.19 & 25.66 & 76.99 & 33.58 & 40.00 & 0 & 57.17 & 20.15 \\
\hline & JEV & ND & ND & ND & ND & ND & ND & ND & ND & 37.00 & 9.17 \\
\hline & LACV & ND & ND & ND & ND & ND & ND & ND & ND & 23.86 & 6.69 \\
\hline & MAYV & 11.88 & 3.31 & 20.00 & 0.00 & 4.07 & 1.32 & ND & ND & 3.46 & 0.69 \\
\hline & OROV & 6.67 & 5.20 & $\mathrm{ND}$ & ND & ND & ND & ND & ND & ND & ND \\
\hline & POTV & 26.26 & 17.06 & ND & ND & ND & ND & ND & ND & ND & ND \\
\hline & RRV & 80.66 & 23.02 & ND & ND & ND & ND & ND & ND & 41.40 & 16.57 \\
\hline & RVFV & 69.26 & 27.24 & 60.04 & 6.34 & 40.72 & 11.96 & 15.00 & 7.07 & 6.54 & 4.67 \\
\hline & VEEV & 71.20 & 20.49 & 89.48 & 10.48 & 64.78 & 22.53 & 59.94 & 26.57 & 38.09 & 23.53 \\
\hline & WNV & 73.41 & 23.81 & 94.39 & 3.91 & 69.80 & 23.98 & 82.72 & 11.49 & 68.63 & 18.62 \\
\hline \multirow{11}{*}{$\begin{array}{l}\text { Intrathoracic } \\
\text { injection }\end{array}$} & AMTV & 100.00 & ND & ND & ND & ND & ND & ND & ND & ND & ND \\
\hline & BUJV & 100.00 & ND & ND & ND & ND & ND & ND & ND & ND & ND \\
\hline & CHIV & 96.88 & ND & ND & ND & ND & ND & ND & ND & ND & ND \\
\hline & ICOV & 40.91 & ND & ND & ND & ND & ND & ND & ND & ND & ND \\
\hline & ITPV & 81.25 & ND & ND & ND & ND & ND & ND & ND & ND & ND \\
\hline & KARV & 94.12 & ND & ND & ND & ND & ND & ND & ND & ND & ND \\
\hline & ORUV & 37.50 & 17.68 & ND & ND & ND & ND & ND & ND & 37.50 & 17.68 \\
\hline & PACV & 100.00 & 0.00 & ND & ND & ND & ND & ND & ND & ND & ND \\
\hline & RVFV & ND & ND & ND & ND & ND & ND & ND & ND & 15.93 & 7.35 \\
\hline & SALV & 92.86 & 0.00 & ND & ND & ND & ND & ND & ND & ND & ND \\
\hline & URUV & 94.12 & 0.00 & ND & ND & ND & ND & ND & ND & ND & ND \\
\hline \multirow{16}{*}{$\begin{array}{l}\text { Membrane } \\
\text { feeding }\end{array}$} & CHIKV & 58.92 & 28.23 & 77.58 & 22.60 & 79.06 & 23.45 & 53.49 & 33.98 & 42.68 & 23.78 \\
\hline & CVV & 56.50 & 0.00 & 100.00 & 0.00 & ND & ND & 29.60 & 0.00 & 17.39 & 0.00 \\
\hline & DENV-1 & 60.18 & 16.01 & 63.79 & 23.97 & 39.56 & 23.90 & 8.33 & 0.00 & 6.25 & 0.00 \\
\hline & DENV-2 & 58.10 & 30.93 & 53.12 & 22.93 & 34.83 & 18.81 & 12.47 & 13.20 & 10.13 & 12.29 \\
\hline & GETV & 100.00 & 0.00 & ND & ND & ND & ND & ND & ND & ND & ND \\
\hline & $\mathrm{JCV}$ & 96.67 & 0.00 & 89.66 & 0.00 & 86.67 & 0.00 & 7.69 & 0.00 & 6.67 & 0.00 \\
\hline & JEV & 91.98 & 10.72 & 90.79 & 14.56 & 84.63 & 19.92 & ND & ND & 40.50 & 15.98 \\
\hline & KEYV & 91.89 & 0.00 & 91.18 & 0.00 & 83.78 & 0.00 & ND & ND & ND & ND \\
\hline & LACV & 89.72 & 7.38 & 86.83 & 13.70 & 71.03 & 22.93 & 35.84 & 14.25 & 29.93 & 16.75 \\
\hline & POTV & 93.55 & 6.59 & 96.13 & 3.21 & 89.86 & 5.96 & ND & ND & 14.67 & 7.00 \\
\hline & RVFV & 10.53 & 0.00 & 25.00 & 0.00 & 2.63 & 0.00 & 100.00 & 0.00 & 2.63 & 0.00 \\
\hline & TVTV & 28.00 & 0.00 & 85.71 & 0.00 & 24.00 & 0.00 & ND & ND & ND & ND \\
\hline & USUV & 64.40 & 31.2 & 0.00 & 0.00 & 0.00 & 0.00 & 0.00 & 0.00 & 0.00 & 0.00 \\
\hline & WNV & 32.61 & 24.53 & 64.59 & 25.58 & 20.33 & 16.96 & ND & ND & ND & ND \\
\hline & YFV & 33.18 & 21.18 & 55.52 & 20.97 & 20.86 & 10.90 & 36.52 & 26.17 & 7.68 & 5.94 \\
\hline & ZIKV & 67.19 & 23.70 & 38.71 & 21.76 & 29.25 & 22.80 & 24.62 & 22.46 & 9.21 & 6.91 \\
\hline
\end{tabular}

Infection rate: number of mosquitoes showing virus infection in the gut divided by the number of mosquitoes fed with infected blood $x$ 100. Infection: percentage of mosquitoes in which the virus was detected after 7-10 day of incubation following intrathoracic injection of the indicated virus. For this test, the ground mosquito suspension was inoculated in rats, or the virus presence was quantified by assays in Vero cells. ND: Not described SD: standard deviation AMTV, Arumowot virus; BUJV, Bujaru virus; CHIKV, Chikungunya virus; CVV, Cache Valley virus; CHPV, Chandipura virus; CHIV, Chilibre virus; DENV-1, Dengue virus serotype 1; DENV-2, Dengue virus serotype 2; EEEV, Eastern Equine Encephalomyelitis virus; GETV, Getah virus; ICOV, Icoaraci virus; ITPV, Itaporanga virus; JCV, Jamestown Canyon virus; JEV, Japanese Encephalitis virus; KARV, Karimabad virus; KEYV, Keystone virus; LACV, La Crosse virus; MAYV, Mayaro virus; OROV, Oropuche virus; ORUV, Orungo virus; PACV, Pacui virus; POTV, Potosi virus; RVFV, Rift Valley fever virus; RRV, Ross River virus; SALV, Salehabad virus; SAV, San Angelo virus; SLEV, St. Louis encephalitis virus; TENV, Tensaw virus; TVTV, Trivittatus virus; URUV, Urucuri virus; USUV, Usutu virus; VEEV, Venezuelan equine encephalitis virus; WNV, West Nile virus; YFV, Yellow fever virus; and ZIKV, Zika virus. For BSQV, Bussuquara virus, ILHV, Ilheus virus, KOKV, Kokobera virus, KUNV, Kunjin virus, UGSV, and Uganda S. virus, only transovarial transmission tests were described.

Comparison of IR, DE, and TE (see Methods and Supplementary Table S7) values calculated for known efficient bridge vectors infected with different arboviruses, and those for Ae. albopictus (Table 3) showed that the YFV TE rate for Ae. albopictus $(7.68 \% \pm 5.9)$ was similar to the rate calculated for Haemagogus leucocelenus [127] $(8.08 \% \pm 2.0)$. Conversely, the TE rates varied more for WNV: $68.6 \% \pm 18.6$ for Ae. albopictus and $13.49 \pm 14.8$ for Culex pipiens (a primary vector of WNV in the 
field) [117,124,137-146]. Moreover, Ae. albopictus and Ae. aegypti (a recognized epidemic vector) showed similar TE rates for CHIKV [126,147-152], DENV-1 [153-157], and DENV-2 [126,147,154,155,157-159], but Ae. aegypti was more efficient at transmitting ZIKV [126,160-171] and YFV [127,128,172-175].

Table 3. Comparison of the infection rate, dissemination efficiency, and transmission efficiency (mean and standard deviation) for Aedes albopictus and other mosquito vectors.

\begin{tabular}{ccccc}
\hline Mosquito Species & Virus & IR (\%) & DE (\%) & TE (\%) \\
\hline Aedes aegypti & CHIKV & NA & $98.3 \pm 3.8$ & $42.92 \pm 20.19$ \\
& DENV-1 & $37.7 \pm 27$ & $34.4 \pm 24.9$ & $4.9 \pm 4.6$ \\
& DENV-2 & $44.4 \pm 33.4$ & $33.3 \pm 24.2$ & $5 \pm 0$ \\
& ZIKV & $69.0 \pm 27.4$ & $44.0 \pm 28.3$ & $20.48 \pm 26.87$ \\
& YFV & $46.4 .0 \pm 23.6$ & $21.3 \pm 19.0$ & $16.5 \pm 17.7$ \\
\hline Aedes albopictus & CHIKV & $58.9 \pm 28.2$ & $79.0 \pm 23.4$ & $42.68 \pm 23.7$ \\
& DENV-1 & $60.2 \pm 16$ & $39.5 \pm 24.2$ & $6.25 \pm 0$ \\
& DENV-2 & $58.0 \pm 30.9$ & $34.8 \pm 18.8$ & $10.13 \pm 12.28$ \\
& WNV & $63.8 \pm 29.2$ & $58.1 \pm 30.8$ & $68.6 \pm 18.6$ \\
& YFV & $33.1 \pm 21.1$ & $20.8 \pm 10.8$ & $7.68 \pm 5.9$ \\
& ZIKV & $67.1 \pm 23.7$ & $29.2 \pm 22.8$ & $9.21 \pm 6.9$ \\
\hline Culex pipiens & WNV & $47.7 \pm 33.7$ & $30.4 \pm 29.7$ & $13.49 \pm 14.8$ \\
& YFV & $50.9 \pm 4.0$ & $30.06 \pm 1.6$ & $8.08 \pm 2.0$ \\
\hline
\end{tabular}

IR, infection rate; DE, dissemination efficiency; TE, transmission efficiency; CHIKV, Chikungunya virus; DENV-1, Dengue serotype 1; DENV-2, Dengue serotype 2; WNV, West Nile virus; YFV, Yellow fever virus; ZIKV, Zika vírus.

\section{Discussion}

In the present work, we tried to understand the potential role of the Asian tiger mosquito Ae. albopictus as a bridge vector that might favour the transfer of zoonotic arboviruses from enzootic or domestic hosts to humans and vice-versa. To this aim, we evaluated its ability to colonize natural breeding sites in newly invaded and native areas, its appetence for animal blood sources, and its global efficiency for transmitting arboviruses. This mosquito species was described as capable of developing infection from a large number of arboviruses in laboratory conditions [36]. However, based on the published evidences of vector competence, we found that transmission by Ae. albopictus is proven only for 14 of them, without considering the epidemic Aedes-borne CHIKV, DENV (4 serotypes), and ZIKAV.

In relation to the capacity of Ae. albopictus to establish in natural areas (rural/sylvan environments), tree holes were described as the most common natural breeding sites, although it has been detected also in bamboo stumps, and more sporadically in rock holes and plant axils [24]. Our analysis indicates that coconut shells, bromeliads, and bamboo stumps might be as common as tree holes, whereas rock holes and leaf axils of other plants are less frequently used. These results might be biased due to differences across studies related to sampling efforts and the environmental characteristics of sampled areas. Therefore, they should be confirmed by comparisons with larval sampling in natural and artificial breeding sites in natural areas and forest edges. Moreover, when possible, the productivity in these habitats should be described and compared by pupal sampling, with the same methodology used for quantifying the productivity of anthropic containers in urban areas [176]. For example, a study in Rio de Janeiro showed that the percentage of Ae. albopictus larvae in bromeliads corresponded to $0.18 \%$ of all sampled larva, demonstrating the low productivity of this breeding place [48]. However, studies describing the productivity of natural breeding sites in the natural environment or at an interface between natural and man-modified environments are lacking. In native forested areas, natural containers of larvae (tree holes, bamboo stumps, rock holes) were observed at the forest edge, like in a colonized forested area. Breeding sites in the deep forest have never been detected for this species [24,27].

Our results also confirmed the opportunistic feeding behaviour of Ae. albopictus and its strong preference for mammals, especially humans (humans $=60 \%$, non-humans $=30 \%$ ) compared with 
other groups, such as birds (4\%). Ae. albopictus can feed on 28 different biological families. Reports on Ae. albopictus biting on any primates other than man were lacking until very recently. Specifically, a study described Ae. albopictus probing on a howler monkey that had just died due to YFV and was lying on the forest edge in Brazil [177]. This mosquito also bites domesticated animals-Muridae, Canidae, Phasianidae, Herpestidae, and Bovinae. Several studies suggested this opportunism. For instance, laboratory experiments on the host choice showed that this mosquito preferentially bites humans compared with other animals [30]. This opportunism was confirmed in studies on blood-fed mosquitoes collected in the field $[27,30,69,78]$. From our literature analysis, birds appeared as a non-preferential host group. Based on the reported proportion of blood meals, domestic and peri-domestic animals $(25 \%)$ should be considered more relevant than wildlife (10\%) as sources of zoonotic pathogens for Ae. albopictus. However, a limited number of studies were carried out in natural habitats where wildlife is abundant. Therefore, additional research is needed in natural areas to precisely describe the blood feeding patterns of Ae. albopictus and its interaction with wildlife. If possible, the availability of vertebrate hosts should be taken into account by using field census procedure and by calculating indexes of feeding preferences [178]. Such approaches should prevent the underestimation of the Ae. albopictus' potential to transmit pathogens from domestic/sylvatic vertebrate hosts to humans, but also from domestic to sylvatic vertebrate hosts, and vice versa. Our analysis also highlighted a huge variability in the proportion of human blood meals. This is a relevant factor for calculating the vector capacity, the disease reproduction rate (Ro), and the spill-over risk that may be determined by several parameters [178].

Concerning vector competence, this species was suggested as a potential vector for many viruses. It is important to emphasize that the mean TE values of enzootic viruses, such as WNV $(68.6 \% \pm 18.6)$, $\operatorname{EEEV~}(57.16 \% \pm 20.14), \operatorname{RRV}(41.39 \% \pm 16.5), \operatorname{JEV}(39.3 \% \pm 13.5), \operatorname{VEEV}(38.1 \% \pm), \operatorname{LACV}(27.3 \% \pm 12.87)$, CVV $(17.4 \% \pm 0)$, and POTV $(14.6 \% \pm 7)$, were higher or comparable with those reported for epidemic viruses, such as DENV-1 (6.25 \pm 0$)$, DENV-2 (10.13 \pm 12.28$)$, YFV (7.68 \pm 5.9$)$, ZIKV $(9.21 \pm 6.9)$, CHPV $(12.5 \% \pm 0)$, YFV $(8.2 \% \pm 6)$, JCV $(6.6 \% \pm 0)$, RVFV $(5.2 \% \pm 3.9)$, and MAYV $(3.5 \% \pm 0.69)$. The large difference in TE rates between enzootic and epidemic viruses is a reflection of the techniques employed to assess parameters. Most of the analysis on enzootic viruses were performed mainly in the 1990s and up to the beginning of the 2000s. Conversely, epidemic viruses were analysed using more precise techniques during the last 5 years. Despite the biases of the older methodologies, Ae. albopictus presented a high TE rate for enzootic arboviruses; therefore, it might transmit these viruses if taken from viremic natural vertebrates.

Comparing the vector competence of Ae. aegypti and Ae. albopictus for different epidemic viruses did not allow for a conclusion that there is a difference in their TE rates for ZIKV, CHIKV, DENV-1, and DENV-2. However, for bridge vectors*virus pairs, WNV TE was higher for Ae. albopictus than for $C x$. pipiens, contrary to what was expected. Although the WNV transmission efficiency rate by Ae. albopictus is high in experimental conditions, this species has never been incriminated as a WNV vector in the field, possibly due to its low propensity to bite birds. Ae. albopictus presented similar TE rates as Hg. leucocelenus, a primary YFV vector within and at the edges of Brazilian forests [27,179]. However, few studies have been carried out to assess $\mathrm{Hg}$. leucocelenus vector competence. In general, the contribution of laboratory studies for assessing the role of vector(s) in natural environments is limited.

Based on vector competence and blood meal studies, we conclude that Ae. albopictus could act as a bridge vector for many viruses (e.g., WNV, EEEV, ORUV, RRV, YFV, JEV, VEEV, LACV, RVFV, $\mathrm{CVV}, \mathrm{CHPV}, \mathrm{JCV}$, and MAYV) with a potential risk for disease emergence. One of our goals was to identify in a quantitative way the viruses with a higher risk of emergence, and to develop an analysis to quantify the relative risk of transfer to humans of each enzootic arbovirus that can be efficiently transmitted by Ae. albopictus in laboratory conditions. The methodology used was based on two previous published works [180,181] that quantified the risk of WNV transfer by Culex mosquitoes. We then calculated the relative risk of Ae. albopictus-mediated virus transfer from its natural hosts to 
humans using a simplified version of Kilpatrick's equation (see Supplementary Information for more details concerning the methodology used and Figure S2) that takes into account Ae. albopictus vector competence for a given virus (i.e., TE), and the mean relative feeding frequencies on humans (FHi) and on animal hosts (FAi). Unfortunately, this analysis was hindered by the limited information available on the enzootic/sylvatic reservoirs of several of these arboviruses (some hosts remain unknown or are not sufficiently identified). Moreover, some viruses have many potential reservoirs, and their objective weighting is difficult. Additionally, data on Ae. albopictus propensity to bite a given animal reservoir species are often lacking (e.g., primates). Consequently, only biting frequencies at animal family levels could be used, leading to overly unreliable and speculative risk transfer estimates. Therefore, we chose not to include them here, although these estimates are crucial to better assess the risk of spill-over and emergence of enzootic arboviruses in relation with the secondary invasion of Ae. albopictus in forested areas.

Another important limitation of the present work is the great methodological variation and the lack of standardization of the protocols used to assess the vector competence of Ae. albopictus. Vector competence for arboviruses is influenced by genetic factors in the mosquito population and in the virus strain, such as the geographical genetic origin of the vector population or the interaction between the vector and arbovirus genotype $[182,183]$. Therefore, the intraspecific genetic variability in mosquito species/populations, as well as the intra- and inter-specific variability of arboviruses can affect vector competence and risk estimations. External factors, such as the incubation temperature, can also affect vector competence, and consequently the transmission and analysis of the risk [184].

Other factors interfering with the vector competence results are the way of ingesting the virus-infected blood (in vivo or in vitro), the viral load concentration, and the sensibility of the method used to detect the virus in the mosquito body or saliva. We are aware that our study is limited due to the methodological differences of the analysed articles, and also because the risk of arbovirus emergence is a multifactorial process and it is actually impossible to estimate the interactions of all factors with the limited evidences available. Thus, more standardized studies of vector competence and blood feeding preferences are necessary. In this sense, the project Infravec2 (https://infravec2.eu) is an important international initiative, and one of its themes is the standardization of methods.

In conclusion, data from the literature show that Ae. albopictus can colonize forest environments, and has possible interactions with domestic animals and wildlife, suggesting a risk for interaction with animal viruses. Such a risk is particularly high in areas that are considered to be biodiversity hotspots, such as the Congo and Amazon Basin forests. The presence of Ae. albopictus in small towns and hamlets in the Amazon Forest highlights the risk of spill-over of some arboviruses that cause human diseases, such as OROV, YFV, and MAYV [27]. In Brazil, Ae. albopictus populations are experimentally competent for YFV transmission, but this has not been confirmed by infecting Ae. albopictus [127,185]. In Africa, many arboviruses could be investigated to elucidate their potential transmission and emergence facilitated by Ae. albopictus, as done for CHIKV [152]. In the United States, where this mosquito species is widespread, its potential role in LACV, EEEV, WNV, and POTV transmission must be investigated [36,133,135]. In Asia and Oceania, the potential for inter-species transmission of JEV and RRV must be evaluated. It is important to take into account that the risk of arbovirus emergence is dynamic and in continuous evolution because mosquito populations, virus genetics, and the possibility of their contact varies according to time and place, and adaptations could be expected, particularly for invasive pathogens and vectors [186]. For instance, in the Indian Ocean region, the interaction between Ae. albopictus and CHIKV led to the selection of a virus strain that infects vectors and can spread around the world more easily. Studies on mutation selection for more susceptible arbovirus strains are still limited, but can be useful for predicting spill-over events [187]. Also, vector competence must be evaluated with as many strains as possible to maximize viral diversity, if possible using strains recently isolated from animals.

Our literature review showed that Ae. albopictus is competent for many different arboviruses, is present in natural habitats and forest edges, and can feed on several animal groups [30]. All these 
features make of Ae. albopictus a potential bridge vector of several emerging arboviruses (at least 14 viruses [23,36]), thus increasing the risk of spill-over and spill-back events. We hope that our approach will encourage more research to disentangle this risk in the field and the laboratory, with the aim of preventing the emergence of zoonotic diseases and reducing potential health and economic burdens, particularly for vulnerable populations.

\section{Material and Methods}

\subsection{Natural Breeding Sites}

First, a literature search was done in Google Scholar to identify articles reporting the presence of Ae. albopictus in natural larval breeding sites and their types, using the keywords "Natural Breeding sites Aedes albopictus" or "Oviposition sites Aedes albopictus" or "Larval habitats Aedes albopictus". This allowed for the identification of 16 articles [43,44,46,52,54,55,61,62,188-194] (Supplementary Table S1). From these articles, the main natural breeding sites were listed: bamboo stumps, bromeliads, coconut shells, leaf axils, rock holes, tree holes, snail shells, cacao shells, puddles, dead cow horns, dead leaves, ground cavity, hollow log, palm bracts, and palm leaves. Then, a search on each type of natural breeding site was carried out using PubMed, using the following words: (Aedes albopictus [Title/Abstract] AND "Breeding type" [Title/Abstract]). The aim of this search was to quantify the number of articles and the number of detections that described the presence of this mosquito in each of the identified natural breeding sites (Supplementary Table S2). Articles that did not quantify the number of times the breeding sites were found positive were excluded. The bibliographic search was done between August and December 2018.

\subsection{Feeding Behaviour}

A literature search was done in Google Scholar with the key words "blood meal" and "host feeding", followed by "Aedes albopictus" until December 2018. Three studies were excluded because they were considered unreliable: (i) the study by Gingrich and Williams, 2005 [67], which did not test for human blood meals, thus bringing a potential bias into the results; (ii) the study performed in a zoo by Tuten et al., 2012 [195]; and (iii) the study by Hess et al., 1968 [196] that was exclusively carried out in a bird area on Hawaii Island. Finally, 22 studies were selected (see references and details for each of them in Supplementary Table S3) to build a database of blood feeding preferences, based on the Ae. albopictus biting frequency for each host species, biological family, or group of vertebrate hosts (human, mammals, birds, domestic animals, wild animals). The database was used to quantify the relative importance as a blood meal of each host group and of specific hosts, based on the reported blood meal sources identified using different techniques (DNA sequencing, ELISA blond meal analyses, agarose gel precipitin). Then, these preferences were analysed independently of the host availability, which was quantified in very few studies.

\subsection{Arbovirus Transmission}

First, all referenced arboviruses that might be transmitted by Ae. albopictus were selected using the arbocat database from Centers for Disease Control and Prevention (CDC) (https://wwwn.cdc.gov/ arbocat/VirusBrowser.aspx). Then, Google Scholar and PubMed were searched with the key words "Virus name" and "Vector Competence", followed by "Aedes albopictus". Among the 49 articles obtained with this search, articles containing data on virus detection/isolation from field-collected mosquitoes, and data on vector competence parameters, including "susceptibility", "infection, dissemination", or "transmission rates" were selected (see Supplementary Table S4 showing the viruses and the bibliographic references). Data from each article were used to calculate the infection rates as the number of mosquitoes showing virus infection in the gut divided by the number of mosquitoes fed with infected blood $x$ 100. Dissemination efficiency was calculated as the number of mosquitoes with viruses disseminated in the legs, wings, or head divided by the number of mosquitoes fed with 
infected blood $x$ 100. Transmission rates were calculated as the number of mosquitoes that could deliver the virus with saliva (detection of virus in mosquito saliva, or demonstration of transmission using animal hosts exposed to infected mosquito bites) divided by the number of mosquitoes with viruses disseminated in the legs, wings, or head (body) $\times 100$. Transmission efficiency was calculated as the number of mosquitoes that could deliver the virus with saliva (detection of living viruses or viral genome in mosquito saliva, or demonstration of transmission using animal hosts exposed to infected mosquito bites) divided by the number of mosquitoes fed with infected blood [168]. In the present work, infection performed from intrathoracic assays corresponds to mosquitoes that after intrathoracic injection, were detected with the virus after a 7-10 day incubation period. For this detection, the ground mosquito suspension was inoculated in rats, or the presence of the virus quantified by assays in Vero cell cultures. After intrathoracic injection, infected mosquitoes may transmit the virus to another animal. Some articles only described transovarial transmission tested after intrathoracic infection. These works demonstrated Ae. albopictus susceptibility to develop infection by a given arbovirus. However, these articles did not quantify the infection and transmission rates.

To compare the results, the same bibliographic search was performed to find the vector competence values reported for efficient bridge vector-virus pairs, such as Culex pipiens * WNV and Haemagogus leucocelenus * YFV, and for epidemic vector-virus pairs, such as Aedes aegypti * YFV, Aedes albopictus ${ }^{*} \mathrm{DENV}$ 1, Aedes albopictus ${ }^{*} \mathrm{DENV} 2$, Aedes aegypti ${ }^{*} \mathrm{DENV} 1$, Aedes aegypti ${ }^{*} \mathrm{DENV} 2$, Aedes albopictus ${ }^{*} \mathrm{CHIKV}$, Aedes aegypti * CHIKV, Aedes albopictus *ZIKV virus, and Aedes aegypti * ZIKV (Supplementary Table S7). The bibliographic search was done between August 2018 and November 2019.

Supplementary Materials: The following are available online at http://www.mdpi.com/2076-0817/9/4/266/s1, Table S1. List of the 16 articles found by searching Google Scholar to characterize the types of natural breeding sites exploited by Ae. albopictus, Table S2. Typology and number of reported natural containers exploited by Ae. albopictus from articles found in PubMed, Table S3: List of references used to analyse the host feeding preferences of Aedes albopictus, Table S4: List of references that reported infection, infections rate, dissemination rate, dissemination efficiency, transmissions rate or transmission efficiency in Ae. albopictus for the indicated arboviruses, Table S5: List of references used to analyse the vector competence of several mosquito-virus pairs: Aedes aegypti*CHIKV, Aedes aegypti*DENV-1, Aedes aegypti*DENV-2, Aedes aegypti*ZIKV, Aedes albopictus*CHIKV, Aedes albopictus*DENV-1, Aedes albopictus*DENV_2, Aedes albopictus*ZIKV, Culex pipiens*WNV, and Haemagogus leucocelenus*YFV, Table S6: Natural detection or isolation of arboviruses in Ae. albopictus from field-collected mosquitoes. CCV, Cache Valley virus; EEEV, Eastern Equine Encephalomyelitis virus; KEYV, Keystone virus; LACV, La Crosse virus; POTV, Potosi virus; TENV, Tensaw virus; WNV, West Nile virus, Table S7: Geographic distribution, vertebrate hosts and potential vectors of arboviruses isolated or tested for vector competence in $A e$. albopictus. Figure S1. Analysis of the host feeding patterns of Ae. albopictus for the different species of domestic animals without taking into account the host availability.

Author Contributions: T.P.-d.-S., D.R., and C.P. conceived the study and designed the methodology. T.P.-d.-S., D.R., R.L.-d.-O. and C.P. wrote the manuscript. All authors have read and agreed to the published version of the manuscript.

Funding: This study was funded by the French Government Investissement d'Avenir program, Laboratoire d'Excellence "Centre d'Etude de la Biodiversité Amazonienne" (grant ANR-10-LABX-25-01), by the European Union Horizon 2020 Research and Innovation Programme under ZIKAlliance (Grant Agreement no. 734548), the Pasteur Institute via the PTR (grant $\mathrm{n}^{\circ}$ 528) and the ANR PRC TIGERBRIDGE (grant ANR-16-CE35-0010-01). Taissa Pereira dos Santos received a PhD mobility grant (201927/2014-4) from the CNPq "Science without Borders" programme.

Conflicts of Interest: The authors declare that there is no conflict of interest.

\section{References}

1. Whitmee, S.; Haines, A.; Beyrer, C.; Boltz, F.; Capon, A.G.; De Souza Dias, B.F.; Ezeh, A.; Frumkin, H.; Gong, P.; Head, P.; et al. Safeguarding human health in the Anthropocene epoch: Report of the Rockefeller Foundation-Lancet Commission on planetary health. Lancet 2015, 386, 1973-2028. [CrossRef]

2. Taylor, L.H.; Latham, S.M.; Woolhouse, M.E.J.; Lathamt, S.M.; Bush, E. Risk factors for human disease emergence. R. Soc. 2001, 356, 983-989. [CrossRef] [PubMed]

3. Jones, K.K.E.; Patel, N.G.N.; Levy, M.A.; Storeygard, A.; Balk, D.; Gittleman, J.L.; Daszak, P. Global trends in emerging infectious diseases. Nature 2008, 451, 990-993. [CrossRef] [PubMed] 
4. Allen, T.; Murray, K.A.; Zambrana-Torrelio, C.; Morse, S.S.; Rondinini, C.; Di Marco, M.; Breit, N.; Olival, K.J.; Daszak, P. Global hotspots and correlates of emerging zoonotic diseases. Nat. Commun. 2017, 8, 1124. [CrossRef] [PubMed]

5. Karesh, W.B.; Dobson, A.; Lloyd-Smith, J.O.; Lubroth, J.; Dixon, M.A.; Bennett, M.; Aldrich, S.; Harrington, T.; Formenty, P.; Loh, E.H.; et al. Ecology of zoonoses: Natural and unnatural histories. Lancet 2012, 380, 1936-1945. [CrossRef]

6. Vasilakis, N.; Cardosa, J.; Hanley, K.A.; Holmes, E.C.; Weaver, S.C. Fever from the forest: Prospects for the continued emergence of sylvatic dengue virus and its impact on public health. Nat. Rev. Microbiol. 2011, 9, 532-541. [CrossRef] [PubMed]

7. Kilpatrick, A.; Randolph, S. Drivers, dynamics, and control of emerging vector-borne zoonotic diseases. Lancet 2012, 380, 1946-1955. [CrossRef]

8. Weaver, S.C.; Reisen, W.K. Present and future arboviral threats. Antivir. Res. 2010, 85, 328-345. [CrossRef]

9. Go, Y.Y.; Balasuriya, U.B.R.; Lee, C. Zoonotic encephalitides caused by arboviruses: Transmission and epidemiology of alphaviruses and flaviviruses. Clin. Exp. Vaccine Res. 2014, 3, 58-77. [CrossRef]

10. Weaver, S.C.; Barrett, A.D.T. Transmission cycles, host range, evolution and emergence of arboviral disease. Nat. Rev. Microbiol. 2004, 2, 789-801. [CrossRef]

11. Gubler, D. Vector-borne diseases. Rev. Sci. Tech. 2009, 28, 583-588. [CrossRef] [PubMed]

12. Kamgang, B.; Happi, J.Y.; Boisier, P.; Njiokou, F.; Hervé, J.P.; Simard, F.; Paupy, C. Geographic and ecological distribution of the dengue and chikungunya virus vectors Aedes aegypti and Aedes albopictus in three major Cameroonian towns. Med. Vet. Entomol. 2010, 24, 132-141. [CrossRef] [PubMed]

13. Weaver, S.C. Host range, amplification and arboviral disease emergence. Arch. Virol. Suppl. 2005, $19,33-44$.

14. Bhatt, S.; Gething, P.; Brady, O.; Messina, J.; Farlow, A.; Moyes, C. The global distribution and burden of dengue. Nature 2012, 496, 504-507. [CrossRef] [PubMed]

15. Guzman, M.G.; Harris, E. Dengue. Lancet 2015, 385, 453-465. [CrossRef]

16. Staples, E.; Fischer, M. Chikungunya virus in the Americas-what a vectorborne pathogen can do. N. Engl. J. Med. 2014, 371, 887-889. [CrossRef] [PubMed]

17. Hills, S.; Fischer, M.; Petersen, L. Epidemiology of Zika Virus Infection. J. Infect. Dis. 2017, $216,868-874$. [CrossRef]

18. Zanluca, C.; De Melo, V.C.A.; Mosimann, A.L.P.; Dos Santos, G.I.V.; dos Santos, C.N.D.; Luz, K. First report of autochthonous transmission of Zika virus in Brazil. Mem. Inst. Oswaldo Cruz 2015, 110, 569-572. [CrossRef]

19. Ahmed, Q.; Memish, Z. Yellow fever from Angola and Congo: A storm gathers. Trop. Doct. 2017, 47, 92-96. [CrossRef]

20. Possas, C.; Martins, R.M.; de Oliveira, R.L.; Homma, A. Urgent call for action: Avoiding spread and re-urbanisation of yellow fever in Brazil. Mem. Inst. Oswaldo Cruz 2018, 113, 1. [CrossRef]

21. Cordellier, R. L'epidemiologie de la fièvre jaune en Afrique de l'Ouest. Bull. World Health Organ. 1991, 69, 73-84. [PubMed]

22. Klitting, R.; Fischer, C.; Drexler, J.; Gould, E.; Roiz, D.; Paupy, C.; de Lamballerie, X. What Does the Future Hold for Yellow Fever Virus? (II). Genes (Basel) 2018, 9, 425. [CrossRef] [PubMed]

23. Paupy, C.; Delatte, H.; Bagny, L.; Corbel, V.; Fontenille, D. Aedes albopictus, an arbovirus vector: From the darkness to the light. Microbes Infect. 2009, 11, 1177-1185. [CrossRef] [PubMed]

24. Hawley, W. The biology of Aedes albopictus. J. Am. Mosq. Control Assoc. 1988, 4, 1-39.

25. Eritja, R.; Palmer, J.; Roiz, D.; Sanpera-Calbet, I.; Bartumeus, F. Direct Evidence of Adult Aedes albopictus Dispersal by Car. Sci. Rep. 2017, 7, 1e4399. [CrossRef] [PubMed]

26. Savage, H.; Niebylski, M.; Smith, G.; Mitchell, C.; Craig, G. Host-feeding patterns of Aedes albopictus (Diptera: Culicidae) at a temperate North American site. J. Med. Entomol. 1993, 30, 27-34. [CrossRef]

27. Pereira dos Santos, T.; Roiz, D.; de Abreu, F.; Luz Bessa, S.; Santa Lucia, M.; Jiolle, D.; Neves, N.; Simard, F.; Lourenço De Oliveira, R.; Paupy, C. Potential of Aedes albopictus as a bridge vector for zoonotic pathogens at the urban-forest interface of Brazil. Emerg. Microbes Infect. 2018, 7, 191. [CrossRef]

28. Grard, G.; Caron, M.; Mombo, I.M.; Nkoghe, D.; Mboui Ondo, S.; Jiolle, D.; Fontenille, D.; Paupy, C.; Leroy, E.M. Zika Virus in Gabon (Central Africa) - 2007: A New Threat from Aedes albopictus? PLoS Negl. Trop. Dis. 2014, 8, e2681. [CrossRef] 
29. Leroy, E.M.; Nkoghe, D.; Ollomo, B.; Nze-Nkogue, C.; Becquart, P.; Grard, G.; Pourrut, X.; Charrel, R.; Moureau, G.; Ndjoyi-Mbiguino, A.; et al. Concurrent chikungunya and dengue virus infections during simultaneous outbreaks, Gabon, 2007. Emerg. Infect. Dis. 2009, 15, 591-593. [CrossRef]

30. Delatte, H.; Desvars, A.; Bouétard, A.; Bord, S.; Gimonneau, G.; Vourc'h, G.; Fontenille, D. Blood-Feeding Behavior of Aedes albopictus, a Vector of Chikungunya on La Réunion. Vector-Borne Zoonotic Dis. 2010, 10, 249-258. [CrossRef]

31. Flahault, A.; Aumont, G.; Boisson, V.; Lamballerie, X.; Favier, F.; Fontenille, D.; Gauzere, B.; Journeaux, S.; Lotteau, V.; Paupy, C.; et al. Chikungunya, La Réunion et Mayotte, 2005-2006: Une épidémie sans histoire? Sante Publique (Paris) 2007, 19, 165-195.

32. Rezza, G.; Nicoletti, L.; Angelini, R.; Romi, R.; Finarelli, A.; Panning, M.; Cordioli, P.; Fortuna, C.; Boros, S.; Magurano, F.; et al. Infection with chikungunya virus in Italy: An outbreak in a temperate region. Lancet 2007, 370, 1840-1846. [CrossRef]

33. Venturi, G.; Di Luca, M.; Fortuna, C.; Elena Remoli, M.; Riccardo, F.; Severini, F.; Toma, L.; Del Manso, M.; Benedetti, E.; Grazia Caporali, M.; et al. Detection of a chikungunya outbreak in Central Italy Detection of a chikungunya outbreak in Central. Euro Surveill. 2017, 22, 17-00646.

34. Sawabe, K. Autochthonous dengue outbreak in Japan after a blank of 70 years and the future prediction of such cases. Med. Entomol. Zool. 2015, 66, 203-205. [CrossRef]

35. Carvalho, R.G.; Lourenço-De-Oliveira, R.; Braga, I.A. Updating the geographical distribution and frequency of Aedes albopictus in Brazil with remarks regarding its range in the Americas. Mem. Inst. Oswaldo Cruz 2014, 109, 787-796. [CrossRef]

36. Vanlandingham, D.; Higgs, S.; Huang, Y.-J. Aedes albopictus (Diptera: Culicidae) and Mosquito-Borne Viruses in the United States. J. Med. Entomol. 2016, 53, 1024-1028. [CrossRef]

37. Bagny, L.; Delatte, H.; Elissa, N.; Quilici, S.; Fontenille, D.; Adhami, J.; Murati, N.; Adhami, J.; Reiter, P.; Beltrame, A.; et al. Aedes (Diptera: Culicidae) vectors of arboviruses in Mayotte (Indian Ocean): Distribution area and larval habitats. J. Med. Entomol. 2009, 46, 198-207. [CrossRef]

38. Banerjee, S.; Aditya, G.; Saha, G.K. Household disposables as breeding habitats of dengue vectors: Linking wastes and public health. Waste Manag. 2013, 33, 233-239. [CrossRef]

39. Dev, V. Dengue vectors in urban and suburban Assam, India: Entomological observations. Who South-East Asia J. Public Heal. 2014, 3, 5838. [CrossRef]

40. Edillo, F.E.; Roble, N.D.; Otero, N.D. The key breeding sites by pupal survey for dengue mosquito vectors, Aedes aegypti (Linnaeus) and Aedes albopictus (Skuse), in Guba, Cebu City, Philippines. Southeast Asian J. Trop. Med. Public Health 2012, 43, 1365-1374.

41. Rao, B.B.; George, B. Breeding patterns of aedes stegomyia albopictus in periurban areas of Calicut, Kerala, India. Southeast Asian J. Trop. Med. Public Health 2010, 41, 536-540. [PubMed]

42. Shriram, A.N.; Sivan, A.; Sugunan, A.P. Spatial distribution of Aedes aegypti and Aedes albopictus in relation to geo-ecological features in South Andaman, Andaman and Nicobar Islands, India. Bull. Entomol. Res. 2018, 108, 166-174. [CrossRef] [PubMed]

43. Simard, F.; Nchoutpouen, E.; Toto, J.C.; Fontenille, D. Geographic distribution and breeding site preference of Aedes albopictus and Aedes aegypti (Diptera: Culicidae) in Cameroon, Central Africa. J. Med. Entomol. 2005, 42, 726-731. [CrossRef] [PubMed]

44. Thavara, U.; Tawatsin, A.; Chansang, C.; Kong-ngamsuk, W.; Paosriwong, S.; Boon-Long, J.; Rongsriyam, Y.; Komalamisra, N. Larval occurrence, oviposition behavior and biting activity of potential mosquito vectors of dengue on Samui Island, Thailand. J. Vector Ecol. 2001, 26, 172-180. [PubMed]

45. Vijayakumar, K.; Sudheesh Kumar, T.K.; Nujum, Z.T.; Umarul, F.; Kuriakose, A. A study on container breeding mosquitoes with special reference to Aedes (Stegomyia) aegypti and Aedes albopictus in Thiruvananthapuram district, India. J. Vector Borne Dis. 2014, 51, 27-32.

46. Forattini, O.P.; Brito, M. Brief Communication an Unusual Grround Larval Habitat of Aedes albopictus. Rev. Inst. Med. Trop. Sao Paulo 1998, 40, 121-122. [CrossRef]

47. Marques, G.R.; Forattini, O.P. Aedes albopictus in soil bromeliads in Ilhabela, coastal area of Southeastern Brazil. Rev. Saude Publica 2005, 39, 548-552. [CrossRef] 
48. Mocellin, M.G.; Simões, T.C.; do Nascimento, T.F.S.; Teixeira, M.L.F.; Lounibos, L.P.; de Oliveira, R.L. Bromeliad-inhabiting mosquitoes in an urban botanical garden of dengue endemic Rio de Janeiro - Are bromeliads productive habitats for the invasive vectors Aedes aegypti and Aedes albopictus? Mem. Inst. Oswaldo Cruz 2009, 104, 1171-1176. [CrossRef]

49. de Oliveira, V.C.; de Almeida Neto, L.C. Ocorrência de Aedes aegypti e Aedes albopictus em bromélias cultivadas no Jardim Botânico Municipal de Bauru, São Paulo, Brasil. Cad. Saude Publica 2017, 33, e00071016. [CrossRef]

50. O'Meara, G.F.; Cutwa, M.M.; Evans, L.F. Bromeliad-inhabiting mosquitoes in south Florida: Native and exotic plants differ in species composition. J. Vector Ecol. 2003, 28, 37-46.

51. Delatte, H.; Dehecq, J.S.; Thiria, J.; Domerg, C.; Paupy, C.; Fontenille, D. Geographic Distribution and Developmental Sites of Aedes albopictus (Diptera: Culicidae) During a Chikungunya Epidemic Event. Vector Control Southeast Asia 2008, 8, 25-34. [CrossRef] [PubMed]

52. Gilotra, S.K.; Rozeboom, L.E.; Bhattacharya, N.C. Observations on possible competitive displacement between populations of Aedes aegypti Linnaeus and Aedes albopictus Skuse in Calcutta. Bull. World Health Organ. 1967, 37, 437-446. [PubMed]

53. Rozeboom, L.E.; Bridges, J.R. Relative population densities of Aedes albopictus and A. guamensis on Guam. Bull. World Health Organ. 1972, 46, 477-483. [PubMed]

54. Sota, T.; Mogi, M.; Hayamizu, E. Seasonal distribution and habitat selection by Aedes albopictus and Aedes riversi (Diptera: Culicidae) in Northern Kyushu, Japan. J. Med. Entomol. 1992, 29, 296-304. [CrossRef]

55. Gomes, A.; Forattini, O.; Kakitani, I.; Marques, G.; Marques, C.; Marucci, D.; Brito, M. Microhabitats de Aedes albopictus (Skuse) na região do Vale do Paraíba, Estado de São Paulo, Brasil. Rev. Saúde Pública S. Paulo 1992, 26, 108-118. [CrossRef]

56. Müller, G.C.; Kravchenko, V.D.; Junnila, A.; Schlein, Y. Tree-hole breeding mosquitoes in Israel. J. Vector Ecol. 2012, 37, 102-109. [CrossRef]

57. O'Meara, G.F.; Evans, L.F., Jr.; Womack, M.L. Colonization of rock holes by Aedes albopictus in the southeastern United States. J. Am. Mosq. Control Assoc. 1997, 13, 270-274.

58. Sivan, A.; Shriram, A.N.; Sugunan, A.P.; Anwesh, M.; Muruganandam, N.; Kartik, C.; Vijayachari, P. Natural transmission of dengue virus serotype 3 by Aedes albopictus (Skuse) during an outbreak in Havelock Island: Entomological characteristics. Acta Trop. 2016, 156, 122-129. [CrossRef]

59. Urbinatti, P.R.; Menezes, R.M.T.; Natal, D. Sazonalidade de Aedes albopictus em área protegida na cidade de São Paulo, Brasil. Rev. Saude Publica 2007, 41, 478-481. [CrossRef]

60. Pena, C.J.; Gonzalvez, G.; Chadee, D.D. Seasonal prevalence and container preferences of Aedes albopictus in Santo Domingo City, Dominican Republic. J. Vector Ecol. 2003, 28, $208-212$.

61. Kamgang, B.; Ngoagouni, C.; Manirakiza, A.; Nakouné, E.; Paupy, C.; Kazanji, M. Temporal Patterns of Abundance of Aedes aegypti and Aedes albopictus (Diptera: Culicidae) and Mitochondrial DNA Analysis of Ae. albopictus in the Central African Republic. PLoS Negl. Trop. Dis. 2013, 7, e2590. [CrossRef] [PubMed]

62. Marquetti, M.; Bisset, J.; Leyva, M.; Garcia, A.; Rodriguez, M. Comportamiento estacional y temporal de Aedes aegypti y Aedes albopictus en La Habana, Cuba. Rev. Cuba. De Med. Trop. 2008, 60, 62-67.

63. Almeida, P.; Baptista, S.; Sousa, C.; Novo, T.; Ramos, H.; Panella, N.; Godsey, M.; Simões, M.J.; Anselmo, M.L.; Komar, N.; et al. Bioecology and Vectorial Capacity of Aedes albopictus (Diptera: Culicidae) in Macao, China, in Relation to Dengue Virus Transmission. J. Med. Entomol. 2005, 42, 419-428. [CrossRef] [PubMed]

64. Colless, D.H. Notes on the culicine mosquitoes of singapore. Ann. Trop. Med. Parasitol. 1959, 51, 87-101. [CrossRef]

65. Dennett, J.A.; Bala, A.; Wuithiranyagool, T.; Randle, Y.; Sargent, C.B.; Guzman, H.; Siirin, M.; Hassan, H.K.; Reyna-Nava, M.; Unnasch, T.R.; et al. Associations between two mosquito populations and West Nile virus in Harris County, Texas, 2003-06. J. Am. Mosq. Control Assoc. 2007, 23, 264-275. [CrossRef]

66. Faraji, A.; Egizi, A.; Fonseca, D.M.; Unlu, I.; Crepeau, T.; Healy, S.P.; Gaugler, R. Comparative Host Feeding Patterns of the Asian Tiger Mosquito, Aedes albopictus, in Urban and Suburban Northeastern USA and Implications for Disease Transmission. PLoS Negl. Trop. Dis. 2014, 8, e3037. [CrossRef] [PubMed]

67. Gingrich, J.B.; Williams, G.M. Host-feeding patterns of suspected West Nile virus mosquito vectors in Delaware, 2001-2002. J. Am. Mosq. Control Assoc. 2005, 21, 194-200. [CrossRef]

68. Gomes, A.; Silva, N.; Marques, G.; Brito, M. Host-feeding patterns of potential human disease vectors in the Paraiba Valley Region, State of Sao Paulo, Brazil. J. Vector Ecol. 2002, 28, 74-78. 
69. Kamgang, B.; Nchoutpouen, E.; Simard, F.; Paupy, C. Notes on the blood-feeding behavior of Aedes albopictus (Diptera: Culicidae) in Cameroon. Parasit. Vectors 2012, 5, 57. [CrossRef]

70. Kek, R.; Hapuarachchi, H.C.; Chung, C.-Y.; Humaidi, M.B.; Razak, M.A.B.A.; Chiang, S.; Lee, C.; Tan, C.-H.; Yap, G.; Chong, C.-S.; et al. Feeding Host Range of Aedes albopictus (Diptera: Culicidae) Demonstrates Its Opportunistic Host-Seeking Behavior in Rural Singapore. J. Med. Entomol. 2014, 51, 880-884. [CrossRef]

71. Kim, K.S.; Tsuda, Y.; Yamada, A. Bloodmeal Identification and Detection of Avian Malaria Parasite From Mosquitoes (Diptera: Culicidae) Inhabiting Coastal Areas of Tokyo Bay, Japan. J. Med. Entomol. 2009, 46, 1230-1234. [CrossRef] [PubMed]

72. Kim, H.; mi Yu, H.; Lim, H.W.; Yang, S.C.; Roh, J.Y.; Chang, K.S.; Shin, E.H.; Ju, Y.R.; Lee, W.G. Host-feeding pattern and dengue virus detection of Aedes albopictus (Diptera: Culicidae) captured in an urban park in Korea. J. Asia. Pac. Entomol. 2017, 20, 809-813. [CrossRef]

73. Muñoz, J.; Eritja, R.; Alcaide, M.; Montalvo, T.; Soriguer, R.C.; Figuerola, J. Host-Feeding Patterns of Native Culex pipiens and Invasive Aedes albopictus Mosquitoes (Diptera: Culicidae) in Urban Zones From Barcelona, Spain. J. Med. Entomol. 2011, 48, 956-960. [CrossRef] [PubMed]

74. Niebylski, M.L.; Savage, H.M.; Nasci, R.S.; Craig, G.B. Blood hosts of Aedes albopictus in the United States. J. Am. Mosq. Control Assoc. 1994, 10, 447-450. [PubMed]

75. Ponlawat, A.; Harrington, L.C. Blood Feeding Patterns of Aedes aegypti and Aedes albopictus in Thailand. J. Med. Entomol. 2005, 42, 844-849. [CrossRef] [PubMed]

76. Richards, S.L.; Ponnusamy, L.; Unnasch, T.R.; Hassan, H.K.; Apperson, C.S. Host-Feeding Patterns of Aedes albopictus (Diptera: Culicidae) in Relation to Availability of Human and Domestic Animals in Suburban Landscapes of Central North Carolina. J. Med. Entomol. 2006, 43, 543-551. [CrossRef]

77. Sawabe, K.; Isawa, H.; Hoshino, K.; Sasaki, T.; Roychoudhury, S.; Higa, Y.; Kasai, S.; Tsuda, Y.; Nishiumi, I.; Hisai, N.; et al. Host-Feeding Habits of Culex pipiens and Aedes albopictus (Diptera: Culicidae) Collected at the Urban and Suburban Residential Areas of Japan. J. Med. Entomol. 2010, 47, 442-450. [CrossRef]

78. Sivan, A.; Shriram, A.; Sunish, I.; Vidhya, P. Host-feeding pattern of Aedes aegypti and Aedes albopictus (Diptera: Culicidae) in heterogeneous landscapes of South Andaman, Andaman and Nicobar Islands, India. Parasitol. Res. 2015, 114, 3539-3546. [CrossRef]

79. Tandon, N.; Ray, S. Host feeding pattern of Aedes aegypti and Aedes albopictus in Kolkata, India. Denuge Bull. 2000, 24, 117-120.

80. Tempelis, C.H.; Hayes, R.O.; Hess, A.D.; Reeves, W.C. Blood-feeding habits of four species of mosquito found in Hawaii. Am. J. Trop. Med. Hyg. 1970, 19, 335-341. [CrossRef]

81. Valerio, L.; Francesca, M.; Bongiorno, G.; Facchinelli, L.; Pombi, M.; Caputo, B.; Maroli, M.; Torre, A. Della Host-Feeding Patterns of Aedes albopictus. Vector-Borne Zoonotic Dis. 2010, 10, 291-294. [CrossRef] [PubMed]

82. Egizi, A.; Healy, S.P.; Fonseca, D.M. Rapid blood meal scoring in anthropophilic Aedes albopictus and application of PCR blocking to avoid pseudogenes. Infect. Genet. Evol. 2013, 16, 122-128. [CrossRef]

83. Tesh, R.B. Multiplication Phlebotomus phlebotomus fever group arboviruses in mosquitoes after intrathoracic inoculation. J. Med. Entomol. 1975, 12,1-4. [CrossRef] [PubMed]

84. Tesh, R.B.; Shroyer, D.A. The mechanism of arbovirus transovarial transmission in mosquitoes: San Angelo virus in Aedes albopictus. Am. J. Trop. Med. Hyg. 1980, 29, 1394-1404. [CrossRef] [PubMed]

85. Armstrong, P.M.; Anderson, J.F.; Farajollahi, A.; Healy, S.P.; Unlu, I.; Crepeau, T.N.; Gaugler, R.; Fonseca, D.M.; Andreadis, T.G. Isolations of Cache Valley virus from Aedes albopictus (Diptera: Culicidae) in New Jersey and evaluation of its role as a regional arbovirus vector. J. Med. Entomol. 2013, 50, 1310-1314. [CrossRef]

86. Ramachandra, R.; Sing, K.; Dhanda, V.; Bhattacharya, N. Experimental transmission of Chandipyura Virus by mosquitoes. Ind. J. Med. Res. 1967, 55, 1306-1310.

87. Mitchell, C.J.; McLean, R.G.; Nasci, R.S.; Crans, W.J.; Smith, G.C.; Caccamise, D.F. Susceptibility parameters of Aedes albopictus to per oral infection with eastern equine encephalitis virus. J. Med. Entomol. 1993, 30, 233-235. [CrossRef]

88. Moncayo, A.C.; Edman, J.D.; Turell, M.J. Effect of eastern equine encephalomyelitis virus on the survival of Aedes albopictus, Anopheles quadrimaculatus, and Coquillettidia perturbans (Diptera: Culicidae). J. Med. Entomol. 2000, 37, 701-706. [CrossRef]

89. Scott, T.W.; Lorenz, L.H.; Weaver, S.C. Susceptibility of Aedes albopictus to infection with eastern equine encephalomyelitis virus. J. Am. Mosq. Control Assoc. 1990, 6, 274-278. 
90. Turell, M.; Beaman, J.; Neely, G. Experimental transmission of Eastern equine encephalitis virus by strains of Aedes albopictus and A. taeniorhynchus (Diptera: Culicidae). J. Med. Entomol. 1994, 31, 287-290. [CrossRef]

91. Takashima, I.; Hashimoto, N. Getah virus in several species of mosquitoes. Trans. R. Soc. Trop. Med. Hyg. 1985, 79, 546-550. [CrossRef]

92. Tesh, R.B. Experimental studies on the transovarial transmission of Kunjin and San Angelo viruses in mosquitoes. Am. J. Trop. Med. Hyg. 1980, 29, 657-666. [CrossRef] [PubMed]

93. Grimstad, P.R. Recently Introduced Aedes albopictus in the United States: Potential vector of La Crosse Virus (Bunyaviridae: California Serogroup). J. Am. Mosq. Control Assoc. 1989, 5, 422-427.

94. Rosen, L.; Tesh, R.B.; Lien, J.; John, H. Transovarial Transmission of Japanese Encephalitis Virus by Mosquitoes. Am. Assoc. Adv. Sci. 1978, 199, 909-911. [CrossRef] [PubMed]

95. Weng, M.H.; Lien, J.C.; Wang, Y.M.; Wu, H.L.; Chin, C. Susceptibility of three laboratory strains of Aedes albopictus (Diptera: Culicidae) to Japanese encephalitis virus from Taiwan. J. Med. Entomol. 1997, 34, $745-747$. [CrossRef] [PubMed]

96. Wispelaere, M.; Desprès, P.; Choumet, V. European Aedes albopictus and Culex pipiens Are Competent Vectors for Japanese Encephalitis Virus. PLoS Negl. Trop. Dis. 2017, 11, e0005294. [CrossRef]

97. Cully, J.F., Jr.; Streit, T.G.; Heard, P.B. Transmission of La Crosse virus by four strains of Aedes albopictus to and from the eastern chipmunk (Tamias striatus). J. Am. Mosq. Control Assoc. 1992, 8, 237-240.

98. Hughes, M.T.; Gonzalez, J.A.; Reagan, K.L.; Carol, D.; Beaty, B.J.; Beaty, B.J. Comparative Potential of Aedes triseriatus, Aedes albopictus, and Aedes aegypti (Diptera: Culicidae) to Transovarially Transmit La Crosse Virus Comparative Potential of Aedes triseriatus, Aedes albopictus, and Aedes aegypti (Diptera: Culicidae). Entomol. Soc. Am. 2006, 43, 757-761.

99. Lambert, A.J.; Blair, C.D.; D'Anton, M.; Ewing, W.; Harborth, M.; Seiferth, R.; Xiang, J.; Lanciotti, R.S. La Crosse Virus in Aedes albopictus Mosquitoes, Texas, USA, 2009. Emerg. Infect. Dis. 2010, 16, 856-858. [CrossRef]

100. Smith, G.C.; Francy, D.B. Laboratory studies of a Brazilian strain of Aedes albopictus as a potential vector of Mayaro and Oropouche viruses. J. Am. Mosq. Control Assoc. 1991, 7, 89-93.

101. Tomori, O.; Aitken, T.H. Orungo virus: Transmission studies with Aedes albopictus and Aedes aegypti (Diptera: Culicidae). J. Med. Entomol. 1978, 14, 523-526. [PubMed]

102. Francy, D.; Krabatsos, N.; Wesson, C.; Moore, J.; Lazuick, J.; Niebylski, T.; Tsai, T.; Craig, J. A new Arbovirus from Aedes albopictus, an Asian mosquito Established in the United States. Science 1990, 250, 1738-1740. [CrossRef] [PubMed]

103. Heard, P.B.; Niebylski, M.L.; Francy, D.B. Transmission of a Newly Recognized Virus (Bunyaviridae, Bunyavirus) Isolated from Aedes albopictus (Diptera: Culicidae) in Potosi, Missouri. J. Med. Entomol. 1991, 28, 601-605. [CrossRef] [PubMed]

104. Mitchell, C.J.; Smith, G.C.; Miller, B.R. Vector Competence of Aedes Albopictus for a Newly Recognized Bunyavirus From Mosquitoes Collected in Potosi, Missouri1. J. Am. Mosq. Control Assoc. 1990, 6, 523-527. [PubMed]

105. Brustolin, M.; Talavera, S.; Nunez, A.; SantamarÍa, C.; Rivas, R.; Pujol, N.; Valle, M.; Verdun, M.; Brun, A.; Pages, N.; et al. Rift Valley fever virus and European mosquitoes: Vector competence of Culex pipiens and Stegomyia albopicta (= Aedes albopictus). Med. Vet. Entomol. 2017, 31, 365-372. [CrossRef] [PubMed]

106. Turell, M.J.; Bailey, C.L.; Beaman, J.R. Vector competence of a Houston, Texas strain of Aedes albopictus for Rift Valley fever virus. J. Am. Mosq. Control Assoc. 1988, 4, 94-96.

107. Mitchell, C.J.; Gubler, D.J. Vector competence of geographic strains of Aedes albopictus and Aedes polynesiensis and certain other Aedes (Stegomyia) mosquitoes for Ross River virus. J. Am. Mosq. Control Assoc. 1987, 3, 142-147.

108. Mitchell, C.J.; Miller, B.R.; Gubler, D.J. Vector competence of Aedes albopictus from Houston, Texas, for dengue serotypes 1 to 4, yellow fever and Ross River viruses. J. Am. Mosq. Control Assoc. 1987, 3, 460-465.

109. Shroyer, D.A. Transovarial Maintenance of San Angelo Virus in Sequenctial Generations of Aedes albopictus. Am J Trop Med Hyg. 1986, 35, 408-417. [CrossRef]

110. Hardy, J.L.; Rosen, L.; Kramer, L.D.; Presser, S.B.; Shroyer, D.A.; Turell, M.J. Effect of rearing temperature on transovarial transmission of St. Louis encephalitis virus in mosquitoes. Am. J. Trop. Med. Hyg. 1980, 29, 963-968. [CrossRef] 
111. Mitchell, C.J. Vector competence of North and South American strains of Aedes albopictus for certain arboviruses: A review. J. Am. Mosq. Control Assoc. 1991, 7, 446-451. [PubMed]

112. Puggioli, A.; Bonilauri, P.; Calzolari, M.; Lelli, D.; Carrieri, M.; Urbanelli, S.; Pudar, D.; Bellini, R. Does Aedes albopictus (Diptera: Culicidae) play any role in Usutu virus transmission in Northern Italy? Experimental oral infection and field evidences. Acta Trop. 2017, 172, 192-196. [CrossRef] [PubMed]

113. Beaman, J.R.; Turell, M.J. Transmission of Venezuelan Equine Encephalomyelitis Virus by Strains of Aedes albopictus (Diptera: Culicidae) Collected from North and South America. J. Med. Entomol. 1991, 28, 161-164. [CrossRef] [PubMed]

114. Fernandez, Z.; Moncayo, A.C.; Carrara, A.S.; Forattini, O.P.; Weaver, A.S.C. Vector Competence of Rural and Urban Strains of Aedes (Stegomyia) albopictus (Diptera: Culicidae) from São Paulo State, Brazil for IC, ID, and IF Subtypes of Venezuelan Equine Encephalitis Virus. J. Med. Entomol 2003, 40, 522-527. [CrossRef] [PubMed]

115. Turell, M.J.; Beaman, J.R. Experimental Transmission of Venezuelan Equine Encephalomyelitis Virus by a strain of Aedes albopictus (Diptera: Culicidae) from New Orleans, Lousiana. J. Med. Entomol. 1992, 29, 802-807. [CrossRef] [PubMed]

116. Baqar, S.; Hayes, C.G.; Murphy, J.R.; Watts, D.M. Vertical transmission of West Nile virus by Culex and Aedes species mosquitoes. Am. J. Trop. Med. Hyg. 1993, 48, 757-762. [CrossRef]

117. Brustolin, M.; Talavera, S.; Santamaría, C.; Rivas, R.; Pujol, N.; Aranda, C.; Marquès, E.; Valle, M.; Verdún, M.; Pagès, N.; et al. Culex pipiens and Stegomyia albopicta (=Aedes albopictus) populations as vectors for lineage 1 and 2 West Nile virus in Europe. Med. Vet. Entomol. 2016, 30, 166-173. [CrossRef]

118. Cupp, E.W.; Hassan, H.K.; Yue, X.; Oldland, W.K.; Lilley, B.M.; Unnasch, T.R. West Nile Virus Infection in Mosquitoes in the Mid-South USA, 2002-2005. J. Med. Entomol. 2007, 44, 117-125. [CrossRef]

119. Farajollahi, A.; Kesavaraju, B.; Price, D.C.; Williams, G.M.; Healy, S.P.; Gaugler, R.; Nelder, M.P. Field efficacy of BG-Sentinel and industry-standard traps for Aedes albopictus (Diptera: Culicidae) and West Nile virus surveillance. J. Med. Entomol. 2009, 46, 919-925. [CrossRef]

120. Holick, J.; Kyle, A.; Ferraro, W.; Delaney, R.; Marta, I. Discovery of Aedes albopictus infected with west nile virus in Southeastern Pennsylvania. J. Am. Mosq. Control Assoc. Inc. 2002, 18, 131.

121. Philip, C.B.; Smadel, J.E. Transmission of West Nile Virus by Infected Aedes albopictus. Proc. Soc. Exp. Biol. Med. 1943, 53, 49-50. [CrossRef]

122. Sardelis, M.R.; Turell, M.J.; Guinn, M.L.O.; Andre, R.G.; Roberts, D.R. Vector Competence of Three North American Strains of Aedes Albopictus for West Nile Virus1. J. Am. Mosq. Control Assoc. 2002, 18, 284-289. [PubMed]

123. Tiawsirisup, S.; Platt, K.B.; Evans, R.B.; Rowley, W.A. A Comparision of West Nile Virus Transmission by Ochlerotatus trivittatus (COQ.), Culex pipiens (L.), and Aedes albopictus (Skuse). Vector-Borne Zoonotic Dis. 2005, 5, 40-47. [CrossRef] [PubMed]

124. Vanlandingham, D.L.; McGee, C.E.; Klinger, K.A.; Vessey, N.; Fredregillo, C.; Higgs, S. Short report: Relative susceptibilties of South Texas mosquitoes to infection with West Nile virus. Am. J. Trop. Med. Hyg. 2007, 77, 925-928. [CrossRef]

125. Fortuna, C.; Remoli, M.E.; Severini, F.; Di Luca, M.; Toma, L.; Fois, F.; Bucci, P.; Boccolini, D.; Romi, R.; Ciufolini, M.G. Evaluation of vector competence for West Nile virus in Italian Stegomyia albopicta (=Aedes albopictus) mosquitoes. Med. Vet. Entomol. 2015, 29, 430-433. [CrossRef]

126. Amraoui, F.; Ayed, W.B.; Madec, Y.; Faraj, C.; Himmi, O.; Btissam, A.; Sarih, M.; Failloux, A.B. Potential of Aedes albopictus to cause the emergence of arboviruses in Morocco. PLoS Negl. Trop. Dis. 2019, 13, e0006997. [CrossRef]

127. Couto-Lima, D.; Madec, Y.; Bersot, M.I.; Campos, S.S.; Motta, M.D.A.; Dos Santos, F.B.; Vazeille, M.; Da Costa Vasconcelos, P.F.; Lourenço-De-Oliveira, R.; Failloux, A.B. Potential risk of re-emergence of urban transmission of Yellow Fever virus in Brazil facilitated by competent Aedes populations. Sci. Rep. 2017, 7, 4848. [CrossRef]

128. Johnson, B.; Chambers, T.; Grabtree, M.; Filippis, A.; Vilarinhos, P.; Resende, M.; Marcoris, L.; Miller, B. Vector competence of Brazilian Aedes aegypti and Ae. abopictus for a Brazilian yellow fever virus isolate * Trans. R. Soc. Trop. Med. Hyg. 2002, 96, 611-613. [CrossRef] 
129. Lourenço de Oliveira, R.; Vazeille, M.; Maria, A.N.A.; Filippis, B.D.E.; Failloux, A. Large genetic differentiation and low variation in vector competence for dengue and yellow fever viruses of Aedes albopictus from Brazil, the United States, and the Cayman Islands. Am. J. Trop. Med. Hyg. 2003, 69, 105-114. [CrossRef]

130. Miller, B.R.; Mitchell, C.J.; Ballinger, M.E. Replication, tissue tropisms and transmission of yellow fever virus in Aedes albopictus. Trans. R. Soc. Trop. Med. Hyg. 1989, 83, 252-255. [CrossRef]

131. Ferreira-De-Lima, V.H.; Lima-Camara, T.N. Natural vertical transmission of dengue virus in Aedes aegypti and Aedes albopictus: A systematic review. Parasites Vectors 2018, 11, 77. [CrossRef] [PubMed]

132. Mitchell, C.J.; Haramis, L.D.; Karabatsos, N.; Smith, G.C.; Starwalt, V.J. Isolation of La Crosse, Cache Valley, and Potosi Viruses from Aedes Mosquitoes (Diptera: Culicidae) Collected at Used-Tire Sites in Illinois during 1994-1995. J. Med. Entomol. 1998, 35, 573-577. [CrossRef]

133. Mitchell, C.J.; Niebylski, M.L.; Smith, G.C.; Karabatsos, N.; Martin, D.; Mutebi, J.P.; Craig, G.B.J.; Mahler, M.J. Isolation of eastern equine encephalitis virus from Aedes albopictus in Florida. Science 1992, 257, 526-527. [CrossRef] [PubMed]

134. Westby, K.M.; Fritzen, C.; Paulsen, D.; Poindexter, S.; Moncayo, A.C. La Crosse Encephalitis Virus Infection in Field-Collected Aedes albopictus, Aedes japonicus, and Aedes triseriatus in Tennessee. J. Am. Mosq. Control Assoc. 2015, 31, 233-241. [CrossRef] [PubMed]

135. Gerhardt, R.R.; Gottfried, K.L.; Apperson, C.S.; Davis, B.S.; Erwin, P.C.; Smith, A.B.; Panella, N.A.; Powell, E.E.; Nasci, R.S. First isolation of La Crosse virus from naturally infected Aedes albopictus. Emerg. Infect. Dis. 2001, 7, 807-811. [CrossRef]

136. Harrison, B.A.; Mitchell, C.J.; Apperson, C.S.; Smith, G.C.; Karabatsos, N.; Engber, B.R.; Newton, N.H. Isolation of potosi virus from Aedes albopictus in North Carolina. J. Am. Mosq. Control Assoc. 1995, 11, 225-229.

137. Fortuna, C.; Remoli, M.E.; Di Luca, M.; Severini, F.; Toma, L.; Benedetti, E.; Bucci, P.; Montarsi, F.; Minelli, G.; Boccolini, D.; et al. Experimental studies on comparison of the vector competence of four Italian Culex pipiens populations for West Nile virus. Parasit. Vectors 2015, 8, 463. [CrossRef]

138. Fros, J.J.; Miesen, P.; Vogels, C.B.; Gaibani, P.; Sambri, V.; Martina, B.E.; Koenraadt, C.J.; van Rij, R.P.; Vlak, J.M.; Takken, W.; et al. Comparative Usutu and West Nile virus transmission potential by local Culex pipiens mosquitoes in north-western Europe. One Heal. 2015, 1, 31-36. [CrossRef]

139. Goddard, L.B.; Roth, A.E.; Reisen, W.K.; Scott, T.W.; States, U. Vector Competence of California Mosquitoes for. Emerg. Infect. Dis. 2002, 8, 1385-1391. [CrossRef]

140. Ebel, G.D.; Rochlin, I.; Longacker, J.; Kramer, L.D. Culex restuans (Diptera: Culicidae) relative abundance and vector competence for West Nile Virus. J. Med. Entomol. 2005, 42, 838-843. [CrossRef]

141. Kilpatrick, A.; Fonseca, D.M.; Ebel, G.D.; Reddy, M.R.; Kramer, L.D. Spatial and temporal variation in vector competence of Culex pipiens and Cx. restuans mosquitoes for West Nile virus. Am. J. Trop. Med. Hyg. 2010, 83, 607-613. [CrossRef] [PubMed]

142. Richards, S.L.; Mores, C.N.; Lord, C.C.; Tabachnick, W.J. Impact of Extrinsic Incubation Temperature and Virus Exposure on Vector Competence of Culex pipiens quinquefasciatus Say (Diptera: Culicidae) for West Nile Virus. Vector-Borne Zoonotic Dis. 2007, 7, 629-636. [CrossRef] [PubMed]

143. Richards, S.L.; Anderson, S.L.; Lord, C.C. Vector competence of Culex pipiens quinquefasciatus (Diptera: Culicidae) for West Nile virus isolates from Florida. Trop. Med. Int. Heal. 2014, 19, 610-617. [CrossRef] [PubMed]

144. Anderson, S.L.; Richards, S.L.; Tabachnick, W.J.; Smartt, C.T. Effects of West Nile Virus Dose and Extrinsic Incubation Temperature on Temporal Progression of Vector Competence in Culex pipiens quinquefasciatus. J. Am. Mosq. Control Assoc. 2010, 26, 103-107. [CrossRef] [PubMed]

145. Turell, M.J.; Guinn, M.L.O.; Dohm, D.J.; Jones, J.W. Vector Competence of North American Mosquitoes (Diptera: Culicidae) for West Nile Virus Vector Competence of North American Mosquitoes (Diptera: Culicidae) for West Nile Virus. J. Med. Entomol. 2001, 38, 130-134. [CrossRef] [PubMed]

146. Vaidyanathan, R.; Fleisher, A.E.; Minnick, S.L.; Simmons, K.A.; Scott, T.W. Nutritional Stress Affects Mosquito Survival and Vector Competence for West Nile Virus. Vector-Borne Zoonotic Dis. 2008, 8, 727-732. [CrossRef]

147. Paupy, C.; Ollomo, B.; Kamgang, B.; Moutailler, S.; Rousset, D.; Demanou, M.; Hervé, J.-P.; Leroy, E.; Simard, F. Comparative role of Aedes albopictus and Aedes aegypti in the emergence of Dengue and Chikungunya in central Africa. Vector Borne Zoonotic Dis. 2010, 10, 259-266. [CrossRef] 
148. Vega-Rúa, A.; Lourenço-De-Oliveira, R.; Mousson, L.; Vazeille, M.; Fuchs, S.; Yébakima, A.; Gustave, J.; Girod, R.; Dusfour, I.; Leparc-Goffart, I.; et al. Chikungunya Virus Transmission Potential by Local Aedes Mosquitoes in the Americas and Europe. PLoS Negl. Trop. Dis. 2015, 9, e0003780. [CrossRef]

149. Vega-Rua, A.; Zouache, K.; Caro, V.; Diancourt, L.; Delaunay, P.; Grandadam, M.; Failloux, A.B. High Efficiency of Temperate Aedes albopictus to Transmit Chikungunya and Dengue Viruses in the Southeast of France. PLoS ONE 2013, 8, e59716. [CrossRef]

150. Honório, N.A.; Wiggins, K.; Câmara, D.C.P.; Eastmond, B.; Alto, B.W. Chikungunya virus vector competency of Brazilian and Florida mosquito vectors. PLoS Negl. Trop. Dis. 2018, 12, e0006521. [CrossRef]

151. Fortuna, C.; Toma, L.; Remoli, M.E.; Amendola, A.; Severini, F.; Boccolini, D.; Romi, R.; Venturi, G.; Rezza, G.; Di Luca, M. Vector competence of Aedes albopictus for the Indian Ocean Lineage (IOL) chikungunya viruses of the 2007 and 2017 outbreaks in italy: A comparison between strains with and without the E1:A226V mutation. Eurosurveillance 2018, 23, 1800246. [CrossRef] [PubMed]

152. Ngoagouni, C.; Kamgang, B.; Kazanji, M.; Paupy, C.; Nakouné, E. Potential of Aedes aegypti and Aedes albopictus populations in the Central African Republic to transmit enzootic chikungunya virus strains. Parasites Vectors 2017, 10, 164. [CrossRef] [PubMed]

153. Calvez, E.; Guillaumot, L.; Girault, D.; Richard, V.; O'Connor, O.; Paoaafaite, T.; Teurlai, M.; Pocquet, N.; Cao-Lormeau, V.M.; Dupont-Rouzeyrol, M. Dengue-1 virus and vector competence of Aedes aegypti (Diptera: Culicidae) populations from New Caledonia. Parasites Vectors 2017, 10, 381. [CrossRef] [PubMed]

154. Gonçalves, C.M.; Melo, F.F.; Bezerra, J.M.T.; Chaves, B.A.; Silva, B.M.; Silva, L.D.; Pessanha, J.E.M.; Arias, J.R.; Secundino, N.F.C.; Norris, D.E.; et al. Distinct variation in vector competence among nine field populations of Aedes aegypti from a Brazilian dengue-endemic risk city. Parasites Vectors 2014, 7, 320. [CrossRef]

155. Poole-Smith, B.K.; Hemme, R.R.; Delorey, M.; Felix, G.; Gonzalez, A.L.; Amador, M.; Hunsperger, E.A.; Barrera, R. Comparison of Vector Competence of Aedes mediovittatus and Aedes aegypti for Dengue Virus: Implications for Dengue Control in the Caribbean. PLoS Negl. Trop. Dis. 2015, 9, e0003462. [CrossRef]

156. Richards, S.L.; Anderson, S.L.; Alto, B.W. Vector Competence of Aedes aegypti and Aedes albopictus (Diptera: Culicidae) for Dengue Virus in the Florida Keys. J. Med. Entomol. 2012, 49, 942-946. [CrossRef]

157. Brustolin, M.; Santamaria, C.; Napp, S.; VerdÚn, M.; Rivas, R.; Pujol, N.; Talavera, S.; Busquets, N. Experimental study of the susceptibility of a European Aedes albopictus strain to dengue virus under a simulted Mediterranean temperature regime. Med. Vet. Entomol. 2018, 32, 393-398. [CrossRef]

158. Chepkorir, E.; Lutomiah, J.; Mutisya, J.; Mulwa, F.; Limbaso, K.; Orindi, B.; Ng'Ang'a, Z.; Sang, R. Vector competence of Aedes aegypti populations from Kilifi and Nairobi for dengue 2 virus and the influence of temperature. Parasites Vectors 2014, 7, 435. [CrossRef]

159. Diallo, M.; Ba, Y.; Faye, O.; Soumare, L.; Dia, I.; Sall, A.A. Vector competence of Aedes aegypti populations from Senegal for sylvatic and epidemic dengue 2 virus isolated in West Africa. Trans. R. Soc. Trop. Med. Hyg. 2008, 102, 493-498. [CrossRef]

160. Heitmann, A.; Jansen, S.; Lühken, R.; Leggewie, M.; Badusche, M.; Pluskota, B.; Becker, N.; Vapalahti, O.; Schmidt-Chanasit, J.; Tannich, E. Experimental transmission of zika virus by mosquitoes from central Europe. Eurosurveillance 2017, 22, 14-17. [CrossRef]

161. Liu, Z.; Zhou, T.; Lai, Z.; Zhang, Z.; Jia, Z.; Zhou, G.; Williams, T. Competence of Aedes aegypti, Aedes albopictus, and Culex quinquefasciatus mosquitoes as Zika Virus Vectors, China. Emerg. Infect. Dis. 2017, 23, 1085-1091. [CrossRef] [PubMed]

162. Di Luca, M.; Severini, F.; Toma, L.; Boccolini, D.; Romi, R.; Remoli, M.E.; Sabbatucci, M.; Rizzo, C.; Venturi, G.; Rezza, G. Experimental studies of susceptibility of Italian Aedes albopictus to Zika virus. Euro Surveill. 2016, $21,18$.

163. Hugo, L.E.; Stassen, L.; La, J.; Gosden, E.; Ekwudu, O.; Winterford, C.; Viennet, E.; Faddy, H.M.; Devine, G.J.; Frentiu, F.D. Vector competence of Australian Aedes aegypti and Aedes albopictus for an epidemic strain of Zika virus. PLoS Negl. Trop. Dis. 2019, 13, e007281. [CrossRef] [PubMed]

164. González, M.A.; Pavan, M.G.; Fernandes, R.S.; Busquets, N.; David, M.R.; Lourenço-Oliveira, R.; García-Pérez, A.L.; Maclel-De-Freitas, R. Limited risk of Zika virus transmission by five Aedes albopictus populations from Spain. Parasites Vectors 2019, 12, 150. [CrossRef]

165. Bonica, M.B.; Goenaga, S.; Martin, M.L.; Feroci, M.; Luppo, V.; Muttis, E.; Fabbri, C.; Morales, M.A.; Enria, D.; Micieli, M.V.; et al. Vector competence of Aedes aegypti for different strains of Zika virus in Argentina. PLoS Negl. Trop. Dis. 2019, 13, e0007433. [CrossRef] 
166. Main, B.J.; Nicholson, J.; Winokur, O.C.; Steiner, C.; Riemersma, K.K.; Stuart, J.; Takeshita, R.; Krasnec, M.; Barker, C.M.; Coffey, L.L. Vector competence of Aedes aegypti, Culex tarsalis, and Culex quinquefasciatus from California for Zika virus. PLoS Negl. Trop. Dis. 2018, 12, e0006524. [CrossRef]

167. Calvez, E.; O'Connor, O.; Pol, M.; Rousset, D.; Faye, O.; Richard, V.; Tarantola, A.; Dupont-Rouzeyrol, M. Differential transmission of Asian and African Zika virus lineages by Aedes aegypti from New Caledonia. Emerg. Microbes Infect. 2018, 7, 159. [CrossRef]

168. Chouin-Carneiro, T.; Vega-Rua, A.; Vazeille, M.; Yebakima, A.; Girod, R.; Goindin, D.; Dupont-Rouzeyrol, M.; Lourenço-de-Oliveira, R.; Failloux, A.B. Differential Susceptibilities of Aedes aegypti and Aedes albopictus from the Americas to Zika Virus. PLoS Negl. Trop. Dis. 2016, 10, e4543. [CrossRef]

169. Hery, L.; Boullis, A.; Delannay, C.; Vega-Rúa, A. Transmission potential of African, Asian and American Zika virus strains by Aedes aegypti and Culex quinquefasciatus from Guadeloupe (French West Indies). Emerg. Microbes Infect. 2019, 8, 699-706. [CrossRef]

170. Richard, V.; Paoaafaite, T.; Cao-Lormeau, V.M. Vector Competence of French Polynesian Aedes aegypti and Aedes polynesiensis for Zika Virus. PLoS Negl. Trop. Dis. 2016, 10, e0005024. [CrossRef]

171. Hall-Mendelin, S.; Pyke, A.T.; Moore, P.R.; Ritchie, S.A.; Moore, F.A.J.; Van Den Hurk, A.F. Characterization of a Western Pacific Zika Virus Strain in Australian Aedes aegypti. Vector-Borne Zoonotic Dis. 2018, 18, 317-322. [CrossRef] [PubMed]

172. Ellis, B.R.; Sang, R.C.; Horne, K.M.; Higgs, S.; Wesson, D.M. Yellow fever virus susceptibility of two mosquito vectors from Kenya, East Africa. Trans. R. Soc. Trop. Med. Hyg. 2012, 106, 387-389. [CrossRef] [PubMed]

173. Yen, P.S.; Amraoui, F.; Rúa, A.V.; Failloux, A.B. Aedes aegypti mosquitoes from guadeloupe (French west indies) are able to transmit yellow fever virus. PLoS ONE 2018, 13, e204710. [CrossRef] [PubMed]

174. Van Den Hurk, A.F.; McElroy, K.; Pyke, A.T.; McGee, C.E.; Hall-Mendelin, S.; Day, A.; Ryan, P.A.; Ritchie, S.A.; Vanlandingham, D.L.; Higgs, S. Vector competence of Australian mosquitoes for yellow fever virus. Am. J. Trop. Med. Hyg. 2011, 85, 446-451. [CrossRef]

175. Jupp, P.G.; Kemp, A. Laboratory vector competence experiments with yellow fever virus and five South African mosquito species including Aedes aegypti. Trans $R$ Soc Trop Med Hyg 2002, 96, 493-498. [CrossRef]

176. Focks, D.A. Review of Entomological Sampling Methods and Indicators for Dengue Vectors; World Health Organization: Geneva, Switzerland, 2004.

177. De Abreu, F.V.S.; Delatorre, E.; Dos Santos, A.A.C.; Ferreira-De-Brito, A.; De Castro, M.G.; Ribeiro, I.P.; Furtado, N.D.; Vargas, W.P.; Ribeiro, M.S.; Meneguete, P.; et al. Combination of surveillance tools reveals that yellow fever virus can remain in the same atlantic forest area at least for three transmission seasons. Mem. Inst. Oswaldo Cruz 2019, 114, e190076. [CrossRef]

178. Silver, J.B. Mosquito Ecology: Field Sampling Methods, 3rd ed.; Springer Netherlands: Dordrecht, The Netherlands, 2008.

179. De Abreu, F.V.S.; Ribeiro, I.P.; Ferreira-de-Brito, A.; dos Santos, A.A.C.; de Miranda, R.M.; Bonelly, I.; Neves, M.S.A.S.; Bersot, M.I.; dos Santos, T.P.; Gomes, M.Q.; et al. Haemagogus leucocelaenus and Haemagogus janthinomys are the primary vectors in the major yellow fever outbreak in Brazil, 2016-2018. Emerg. Microbes Infect. 2019, 8, 218-231. [CrossRef]

180. Kilpatrick, A.; Kramer, L.; Campbell, S.; Alleyne, O.; Dobson, A.; Daszak, P. West Nile Virus Risk Assessment and the Bridge Vector Paradigm. Emerg. Infect. Dis. 2005, 11, 425-429. [CrossRef]

181. Muñoz, J.; Ruiz, S.; Soriguer, R.; Alcaide, M.; Viana, D.S.; Roiz, D.; Vázquez, A.; Figuerola, J. Feeding patterns of potential West Nile virus vectors in south-west Spain. PLoS ONE 2012, 7, 3954. [CrossRef]

182. Failloux, A.; Vazeille, M.; Rodhain, F. Geographic genetic variation in populations of the dengue virus vector Aedes aegypti. J. Mol. Evol. 2002, 55, 653-663. [CrossRef]

183. Lambrechts, L.; Chevillon, C.; Albright, R.; Thaisomboonsuk, B.; Richardson, J.; Jarman, R.; Scott, T. Genetic specificity and potential for local adaptation between dengue viruses and mosquito vectors. Biomed Cent. Evol. Biol. 2009, 9, 160. [CrossRef] [PubMed]

184. Zouache, K.; Fontaine, A.; Vega-Rua, A.; Mousson, L.; Thiberge, J.M.; Lourenco-De-Oliveira, R.; Caro, V.; Lambrechts, L.; Failloux, A.B. Three-way interactions between mosquito population, viral strain and temperature underlying chikungunya virus transmission potential. Proc. R. Soc. Bbiol. Sci. 2014, 281, 20141078. [CrossRef] [PubMed] 
185. Possas, C.; Lourenço de Oliveira, R.; Tauil, P.L.; Pinheiro, F.D.P.; Pissinatti, A.; Venancio da Cunha, R.; Freire, M.; Menezes Martins, R.; Homma, A. Yellow Fever outbreak in Brazil: The puzzle of rapid viral spread and challenges for immunization. Mem. Inst. Oswaldo Cruz 2018, 113, e180278. [CrossRef] [PubMed]

186. Amraoui, F.; Pain, A.; Piorkowski, G.; Vazeille, M.; Couto-Lima, D.; de Lamballerie, X.; Lourenço-de-Oliveira, R.; Failloux, A.B. Experimental Adaptation of the Yellow Fever Virus to the Mosquito Aedes albopictus and Potential risk of urban epidemics in Brazil, South America. Sci. Rep. 2018, 8, 14337. [CrossRef]

187. Tsetsarkin, K.A.; Weaver, S.C. Sequential adaptive mutations enhance efficient vector switching by chikungunya virus and its epidemic emergence. Plos Pathog. 2011, 7, e1002412. [CrossRef]

188. Forattini, O.P.; Marques, G.R.A.M.; Kakitani, I.; De Brito, M.; Sallum, M.A.M. Significado epidemiológico dos criadouros de Aedes albopictus em bromélias. Rev. Saude Publica 1998, 32, 186-188. [CrossRef]

189. Li, Y.; Kamara, F.; Zhou, G.; Puthiyakunnon, S.; Li, C.; Liu, Y.; Zhou, Y.; Yao, L.; Yan, G.; Chen, X.G. Urbanization Increases Aedes albopictus Larval Habitats and Accelerates Mosquito Development and Survivorship. PLoS Negl. Trop. Dis. 2014, 8, e3301. [CrossRef]

190. Hiscox, A.; Kaye, A.; Vongphayloth, K.; Banks, I.; Piffer, M.; Khammanithong, P.; Sananikhom, P.; Kaul, S.; Hill, N.; Lindsay, S.W.; et al. Risk factors for the presence of Aedes aegypti and Aedes albopictus in domestic water-holding containers in areas impacted by the Nam Theun 2 hydroelectric project, Laos. Am. J. Trop. Med. Hyg. 2013, 88, 1070-1078. [CrossRef]

191. Amerasinghe, F.P.; Alagoda, T.S.B. Mosquito oviposition in bamboo traps, with special reference to Aedes albopictus, Aedes novalbopictus and Armigeres subalbatus. Insect Sci. Applic. 1984, 5, 493-500. [CrossRef]

192. Brito, M.D.; Forattini, O.P. Produtividade de criadouros de Aedes aegypti no Vale do Paralba, SP, Brasil. Rev. Saúde Pública 2004, 38, 209-215. [CrossRef]

193. Chan, K.L.; Ho, B.C.; Chan, Y.C. Aedes aegypti (L.) and Aedes albopictus (Skuse) in Singapore City. 2. Larval habitats. Bull. World Health Organ. 1971, 44, 629-633. [PubMed]

194. Delatte, H.; Toty, C.; Boyer, S.; Bouetard, A.; Bastien, F.; Fontenille, D. Evidence of Habitat Structuring Aedes albopictus Populations in Réunion Island. PLoS Negl. Trop. Dis. 2013, 7, e2111. [CrossRef] [PubMed]

195. Tuten, H.C.; Bridges, W.C.; Paul, K.S.; Adler, P.H. Blood-feeding ecology of mosquitoes in zoos. Med. Vet. Entomol. 2012, 26, 407-416. [CrossRef] [PubMed]

196. Hess, A.D.; Hayes, R.O.; Tempelis, C.H. The use of th forage ratio technique in mosquito host preference studies. Mosq. News 1968, 28, 386-389. 